\title{
CONTE v. WYETH: CAVEAT INNOVATOR AND THE CASE FOR PERPETUAL LIABILITY IN DRUG LABELING
}

\begin{abstract}
Martin A. Ramey
[O]ne who misrepresents for his gain and benefit at the expense of human life should be answerable in fraud for all the reasonable and foreseeable consequences of his deception. ${ }^{1}$

—Justice Parbin in Wechsler v. Hoffman-La Roche, Inc. (1950)

Liability for intentional or negligent misrepresentations which threaten physical harm is grounded upon a duty which is coextensive with the foreseeable risk. ${ }^{2}$
\end{abstract}

—Justice Walter J. Relihan, Jr. in Brown v. Neff (1993)

\section{INTRODUCTION}

Since the citadel of privity first crumbled for manufacturers of defective products decades ago, state and federal courts have expanded the foundations of products liability law to include not only purchasers as plaintiffs but "ultimate" bystanders under notions of reasonableness, foreseeability and risk allocation. ${ }^{3}$ During this time, products such as drugs, blood products and

* $\quad$ Martin Ramey received his LL.M., magna cum laude, in Health Law, Policy \& Bioethics from Indiana University School of Law-Indianapolis in December 2009 and his J.D. from the University of San Diego in May 2002. He has practiced products liability, including pharmaceutical and medical device litigation, for over seven years and also serves as an adjunct college instructor.

1. Wechsler v. Hoffman-La Roche, Inc., 99 N.Y.S.2d 588, 590 (N.Y. Sup. Ct. 1950). For a discussion of this opinion, see Section V, infra.

2. Brown v. Neff, 603 N.Y.S.2d 707, 709 (N.Y. Sup. Ct. 1993). In Brown v. Neff, a passenger who had been injured in a truck accident sued an automobile repair shop for his injuries, alleging negligence, breach of warranty, and misrepresentation related to the repair shop's safety inspection. The repair shop moved to dismiss the warranty and misrepresentation claims based on a lack of privity. The trial court agreed and dismissed the warranty claim but allowed the misrepresentation claim to go forward. It concluded that privity was not essential to a cause of action for "intentional or negligent misrepresentation involving the risk of physical harm" under $\$ \S 310$ and 311 of the ReSTATEMENT (SECOND) OF TorTs. Those sections, including $\S 310$ comments $\mathrm{c}$ and $\mathrm{d}$, and $\S 311$ comment $\mathrm{b}$, "make it plain that the offending party may be liable not only to the party in privity but also to those whom the misrepresenter should realize are likely to be imperiled." See Brown, 603 N.Y.S.2d at 709-10.

3. David G. Owen, Symposium, The Evolution of Products Liability Law, 26 Rev. Litig. 955, 965 
medical devices have come to be viewed as distinct from other commodities, particularly with the coming of the Restatement (Third) of Torts: Products Liability. ${ }^{4}$

Indeed, there is good reason for treating drugs and devices differently from automobiles, power tools and toys. For starters, drugs and medical devices treat disease and save countless lives. Drugs, in particular, are highly regulated throughout all stages of the product life cycle, imposing complex obligations on manufacturers that endure from the cradle of design to the drug's ultimate demise in the market. For example, before drug compounds may ever be tested in human subjects, they must be thoroughly investigated under approval of the U.S. Food and Drug Administration ("FDA"). Before a specific drug may be sold, its manufacturer must conduct several phases of clinical trials, each intensifying in scope, and submit literally tens of thousands of pages of results to the FDA as evidence of a drug's safety and efficacy. Even then, the FDA must still approve all labeling for each drug, including a review of company advertising. No other line of consumer products manufactured today bears such heavy regulatory burdens.

But, despite this regulation and their admittedly immense contributions, it is also true that drugs and devices may occasionally cause serious and permanent harm in some patients. ${ }^{5}$ Accordingly, products liability law has adapted to create special notions of defect, duty and evidence seeking to balance the utility of these life-saving products with the rights of patients to recover for injuries from them. In many ways, the evolution of our products liability law with respect to drugs and devices can be characterized by constant choices between these competing policies. ${ }^{6}$

(2007); see also Fleming James, Jr., Products Liability, 34 Tex. L. Rev. 44 n.4 (1955) (noting privity as required by Winterbotten v. Wright, 10 M. \& W. 109, 152 Eng. Rep. 402 (Ex. 1842) was abandoned beginning with Huset v. J.I. Case Threshing Mach. Co., 120 Fed. 865 (8th Cir. 1903)); MacPherson v. Buick Motor Co., 217 N.Y. 382, 111 N.E. 1050 (1916); Carter v. Yardley \& Co., 319 Mass. 92, 64 N.E.2d 693 (1946)

4. See, e.g., Restatement (Third) of Torts: Products Liability $\S 6$, Liability of Commercial Seller or Distributor for Harm Caused by Defective Prescription Drugs and Medical Devices (1998).

5. See Reports Received and Reports Entered Into AERS by Year as of June 30, 2009, Food and Drug Administration (2009), http://www.fda.gov/Drugs/GuidanceComplianceRegulatoryInformation/ Surveillance/AdverseDrugEffects/ucm070434.htm (showing number of adverse events received by FDA's AER [adverse event reporting] system by year).

6. See, e.g., Conte v. Wyeth, Inc., 168 Cal. App. 4th 89, 107 (Cal. App. 2008); see generally Mark D. Shifton, The Restatement (Third) of Torts: Products Liability-The ALI's Cure for Prescription Drug Liability, 29 Fordham Urb. L.J. 2343, 2359-81 (2002); see also Hanberry v. Hearst Corp., 276 Cal. App. 
Over the last 40 years, litigation of pharmaceutical product liability cases has grown more complex. Because such products are inextricably linked to the delivery of health care, cases against drug manufacturers are often overlaid with procedural and substantive laws governing medical malpractice. ${ }^{7}$ Recent decisions have also considered the scope of preemption of the Food Drug \& Cosmetic Act ("FDCA") over state tort law and the availability of reverse bifurcation and mini-trials devoted to issues of general and specific causation as a means of resolving difficult scientific and medical questions. ${ }^{8}$ Today, pharmaceutical "mass torts" are routinely consolidated and resolved or disposed of by state and federal judges throughout the country, who often work in cooperation with one another.

In this litigation, plaintiffs' attorneys have also named pharmacies and physicians as parties alleging claims of strict liability, negligence, breach of warranties, battery, fraud, negligent misrepresentation as well as violations of state unfair business and deceptive practices laws. And, in cases involving generic drugs, plaintiffs have sued not only the generic manufacturer but the manufacturer of the original medication, often referred to as the "brand name manufacturer," "innovator" or "pioneer."

As any litigation goes, there has been a natural ebb and flow to victories on either side. Occasionally, along comes a major decision that changes the landscape and grabs headlines, but rarely does the decision do more than alter the particular strategy of each side. Pharmaceutical mass torts, after all, are like the industry they are based upon — big business. ${ }^{9}$ This article discusses one of these recent cases.

$2 \mathrm{~d} 680,683$ (holding publisher liable for representations in its publication as to quality of another manufacturer's product stating “. . . we are influenced more by public policy than by whether such cause of action can be comfortably fitted into one of the law's traditional categories of liability.").

7. It is not uncommon in failure to warn cases for plaintiffs' lawyers to include health care providers as defendants under the theory that if a sufficient warning were provided, failure to adhere to that warning is a violation of the standard of care. In other cases, plaintiffs may seek to include providers to defeat diversity jurisdiction and keep the case in state court. See, e.g., Purdue Pharma, L.P. v. Estate of Heffner, 904 So. 2d 100 (Miss. 2004).

8. See, e.g., Wyeth v. Levine, 129 S. Ct. 1187, 1195 (U.S. 2009); Merck \& Co., Inc. v. Ernst, 296 S.W.3d 81, 95 (Tex. App.-Houston [14th Dist.] 2009) ("General causation describes whether a substance is capable of causing a particular injury or condition in the general population, while specific causation describes whether a substance caused a particular individual's injury."); In re New York County DES Litigation, 211 A.D.2d 500 (N.Y.A.D. 1995) (noting reverse bifurcation, where damages are tried first, is not an "improvident exercise of [judicial] discretion").

9. For example, recent settlements include the Vioxx products liability litigation estimated at $\$ 4.85$ billion; the Vytorin/Zetia marketing, sales practices and products liability litigation at $\$ 41.5$ million; and the Bextra and Celebrex products liability litigation at \$894 million, among others. 
In November 2008, the Court of Appeal for California's First District held that a manufacturer of a brand name drug could be liable to a plaintiff for injuries she suffered after ingesting the generic form of the medication. This was so even though the plaintiff never took the brand name medication. Instead, the court predicated liability on the basis that the manufacturer had misrepresented or omitted material facts in its original label to the FDA. Because her physician had relied upon that label previously to prescribe the medication to patients, the brand name manufacturer was held liable for its negligent misrepresentations even though a pharmacist later filled the prescription with a generic medication that carried the same label and warnings as the brand name. Prior to this decision, it had been routinely accepted that a pioneer could not be liable to a patient injured solely by a drug manufactured by a generic competitor.

However, the case of Conte $v$. Wyeth shook that foundation and made legal headlines, causing great consternation within the pharmaceutical industry. ${ }^{10}$ Some described the ruling as "aberrant" and as the worst judicial decision of 2008. ${ }^{11}$ Plaintiffs' lawyers, on the other hand, especially those presiding over large mass tort inventories, were re-energized by the expansive decision following an earlier setback in preemption of device claims by the U.S. Supreme Court in Riegel v. Medtronic in early 2008. ${ }^{12}$ Still, many commentators were quick to note that Conte was an anomaly within just one California circuit and, as such, that its precedential value was limited. ${ }^{13}$ Despite that spin and the accompanying doomsday predictions of an unraveling of products liability law, the vast majority of post-Conte courts examining the same issue have refused to embrace its logic. ${ }^{14}$ Rather, they cling to a case that preceded Conte by 14 years from the Fourth Circuit, Foster

10. Conte v. Wyeth, 168 Cal. App. 4th 89 (2008); see Bridget M. Ahmann \& Erin M. Verneris, Brand Name Exposure for Generic Drug Use: Prescription for Liability, 32 HamLine L. Rev. 767 (2009). The authors describe Conte as a "sea change," turning "products liability on its head." Id. at 788.

11. Id. at 788; Jim Beck \& Mark Herrmann, Scorecard: Non-Manufacturer, Brand Name Defendants in Generic Drug Cases, Drug and Device Law Blog (Nov. 12, 2009) [hereinafter Beck \& Herrmann, Scorecard], http://druganddevicelaw.blogspot.com/search/label/Conte.

12. Riegel v. Medtronic, Inc., 552 U.S. 312 (2008) (finding preemption of state tort claims against device manufacturers by FDCA for Class III medical devices approved through the Premarket Approval (PMA) process).

13. Jim Beck \& Mark Herrmann, Closing the Arguments on Conte, Drug and Device Law Blog (Jan. 22, 2009), http://druganddevicelaw.blogspot.com/search/label/Conte. However, on January 21, 2009, the California Supreme Court denied review of the decision (Cal. Supreme Court case no. S169116).

14. See Beck \& Herrmann, Scorecard, supra note 11. 
v. American Home Products Corp., which held that a brand name manufacturer owes no duty of care to users of a generic medication. ${ }^{15}$ Nonetheless, these post-Conte decisions should not be read as suggesting that Conte's analysis is unsound. Instead, this author argues that Conte is founded upon traditional tort principles that have been widely accepted for decades. As such, it deserves its fair place in the sun.

\section{A. Conte-The Facts}

For almost four years, Elizabeth Conte took the generic drug metoclopramide to treat symptoms associated with gastrointestinal esophageal reflux disease (GERD). ${ }^{16}$ As a result of that treatment, she developed a debilitating and permanent neurological condition known as tardive dyskinesia. ${ }^{17}$ Tardive dyskinesia is a neurological condition that causes involuntary bodily movements of the mouth, face, limbs and occasionally, the trunk. ${ }^{18}$ High-risk groups include many of the patients for whom the medication was intended: the elderly, females and diabetics. ${ }^{19}$ For those afflicted with the disorder, it can be socially devastating and even lifethreatening. ${ }^{20}$ There is no known, reliable treatment, although in some patients discontinued use of suspect medications may result in an improvement of symptoms. ${ }^{21}$ For others like Elizabeth Conte, it is permanent. ${ }^{22}$

Although Conte brought suit alleging products liability claims against the generic manufacturers of metoclopramide, she also sued the brand name drug's manufacturer, Wyeth. However, her claims against Wyeth were not product-related. Rather, the claims against Wyeth sounded in fraud and

15. Foster v. American Home Products Corp., 29 F.3d 165 (4th Cir. 1994).

16. GERD, also known as acid reflux disease, occurs when gastric acid from the stomach goes up into the esophagus, often causing inflammation of the esophagus. See Dr. Sanjay Gupta, Burning Question, What Is GERD?, CNN (Dec. 8, 2008), http://www.cnn.com/2008/HEALTH/dailydose/11/19/gerd.info/ index.html.

17. Conte, 168 Cal. App. 4 th at 94 . $(2: 1993)$

18. Dilip V. Jeste \& Michael P. Caligiuri, Tardive Dyskinesia, 19 Schizophrenia Bull. 303

19. P. Jay Pasricha et al., Drug Insight: From Disturbed Mobility to Disordered Movement-A Review of the Clinical Benefits and Medicolegal Risks of Metoclopramide, 3 NATURE CLINICAL PRACTICE: Gastroenterology \& Hepatology 138, 143 (Mar. 2006); Jeste \& Caligiuri, supra note 18, at 303.

20. See Pasricha et al., supra note 19, at 144 . "The abnormal involuntary body movements that characterize TD can produce serious psychosocial problems in patients suffering from this disorder. These patients may be stigmatized. Particularly among outpatients, the shame, guilt, anxiety, and anger that these symptoms can cause may result in depression." Jeste \& Caligiuri, supra note 18, at 310.

21. Id. There is often noted improvement in 30 to $50 \%$ of patients following discontinuation. Id.

22. Id. at 143 . According to estimates, as many as $25 \%$ remain permanently disabled. 
misrepresentation arising from Wyeth's statements in and omissions from its original Reglan ${ }^{\circledR}$ label as it had been submitted to the FDA and publishers of the Physicians' Desk Reference years before. ${ }^{23}$

To buttress her claims, Conte argued that her prescribing doctor testified during deposition that he would have relied upon the Physicians' Desk Reference during his residency when he began prescribing Reglan ${ }^{\circledR}$ to his patients. ${ }^{24} \mathrm{He}$ also testified that he never interacted with anyone on the part of the generic manufacturers concerning metoclopramide nor relied upon any of their labels or prescribing information. Additionally, he lacked any information about whose drug would actually be used to fill his prescription.

The trial court granted summary judgment in favor of both the generic manufacturers and Wyeth. As to the generics, the court granted their argument that their liability was preempted by the FDCA and dismissed the claims because Conte's physician had not relied on any of their warnings or product labeling. ${ }^{25}$ As to Wyeth, who did not join in the generic manufacturers' preemption argument, the court held that Wyeth owed no duty to the plaintiff when she had taken only generic versions of the product. ${ }^{26}$

On appeal, the court reversed the trial court's holding as to Wyeth's potential liability for negligent misrepresentations under California law and affirmed dismissal of the claims against the generic manufacturers for Conte's failure to prove reliance. ${ }^{27}$ Interestingly, Wyeth had argued that Conte's reliance on misrepresentation as a viable cause of action was merely as a surrogate to an otherwise non-availing products liability claim, as Wyeth had not manufactured the product that Conte ingested. But the court disagreed, noting that negligence-based fault standards for failure to warn claims are distinct from those based on strict liability. ${ }^{28}$ Citing to Carlin v. Superior Court, ${ }^{29}$ a case where the California Supreme Court held a drug manufacturer may be liable in strict liability even though its actions were within the standard of care, the court noted:

23. The Physicians' Desk Reference is a commercially published reference containing prescribing information for prescription drugs. Ahmman \& Verneris, supra note 10, at 776. It is published annually by Thompson Medical Economics with two supplements and is distributed free to physicians. Morlino v. Medical Center of Ocean County, 684 A.2d 944, 945 n.1 (N.J. Super. 1996).

24. Conte, 168 Cal. App. 4 th at 99 n.6.

25. Id. at 94 .

26. $I d$.

27. $I d$.

28. Id. at 102 .

29. Carlin v. Superior Court, 13 Cal. 4th 1104, 1112-13 (Cal. 1996). 
[F]ailure to warn in strict liability differs markedly from failure to warn in the negligence context. Negligence law in a failure-to-warn case requires a plaintiff to prove that a manufacturer or distributor did not warn of a particular risk for reasons which fell below the acceptable standard of care, i.e., what a reasonably prudent manufacturer would have known and warned about. Strict liability is not concerned with the standard of due care or the reasonableness of a manufacturer's conduct. The rules of strict liability require a plaintiff to prove only that the defendant did not adequately warn of a particular risk that was known or knowable in light of the generally recognized and prevailing best scientific and medical knowledge available at the time of manufacture and distribution. Thus, in strict liability, as opposed to negligence, the reasonableness of the defendant's failure to warn is immaterial.

Stated another way, a reasonably prudent manufacturer might reasonably decide that the risk of harm was such as not to require a warning as, for example if the manufacturer's own testing showed a result contrary to that of others in the scientific community. Such a manufacturer might escape liability under negligence principles. In contrast, under strict liability principles the manufacturer has no such leeway; the manufacturer is liable if it failed to give warning of dangers that were known to the scientific community at the time it manufactured or distributed the product.' [Citation.] Similarly, a manufacturer could not escape liability under strict liability principles merely because its failure to warn of a known or reasonably scientifically knowable risk conformed to an industry-wide practice of failing to provide warnings that constituted the standard of reasonable care. ${ }^{30}$

Thus, to understand how Conte could deviate from what had been commonly accepted by other courts to this point as the rule in generic-only cases, one must accept the premise that a claim alleging negligent misrepresentation remains independently viable from any product liabilityrelated claims. Some will, in no doubt, argue that Conte's premise merely disguises what is otherwise a products liability claim orchestrated to increase the number of defendants and deep pockets. However, Conte seems to have invalidated that argument: both the trial and appellate courts dismissed the generics for want of reliance. If one were able to preserve the trial court's ruling, then plaintiffs like Conte would be without any remedy for what is an inaccurate and misleading label simply because of the way that pharmaceuticals are manufactured and marketed. Brand name manufacturers would have no liability for want of a purchase of their product. Furthermore, generics could never induce reliance since they generally do not market their drugs to prescribers or patients. In essence, to view Conte as a products liability case would leave plaintiffs like Elizabeth Conte without any remedy. To analyze the propriety of Conte, one must view it as a misrepresentation case. 


\section{B. Conte-The Label}

Metoclopramide is a potent dopamine-receptor blocking antiemetic agent widely used to treat gastrointestinal symptoms and disorders such as vomiting, nausea, diabetic gastroparesis and gastroesophageal reflux disease. ${ }^{31}$ Originally marketed under the brand name Reglan $\AA$, the drug is the only FDA-approved drug for the treatment of diabetic gastroparesis, a condition in which the stomach's ability to empty is delayed. ${ }^{32}$ Other uses of the drug remain "off label." 33

The Food \& Drug Administration first approved metoclopramide for use in 1979; and until the mid-1990s, the drug enjoyed popularity among physicians for its ability to treat upper gastrointestinal tract symptoms. ${ }^{34}$ In 2000 , the drug experienced a resurgence in use due to the withdrawal of a competitor, cisparide, from the market. ${ }^{35}$ Metoclopramide's clinical efficacy is largely dose-dependent and best achieved with continuous dosages. ${ }^{36}$ For this reason, the drug is often prescribed on a chronic basis by physicians, even though according to the original label, only short-term therapy of less than 12 weeks is recommended. ${ }^{37}$

In its original label, Wyeth noted that the frequency of extrapyramidal (neural) side effects associated with the drug was only $0.2 \%$, or roughly 1 in every 500 patients. ${ }^{38}$ Later studies put the frequency closer to $29 \% .{ }^{39}$ Despite those studies, Wyeth did not update its label to reflect the additional studies, nor did the company conduct any further safety studies regarding the longterm use of the medication for the prevalence of tardive dyskinesia. Wyeth caused an entry for Reglan ${ }^{\circledR}$ to be published in the PDR from 1980 through

\footnotetext{
31. Christopher Kenney, MD, et al., Metoclopramide, An Increasingly Recognized Cause of Tardive Dyskinesia, 48 J. Clinical Pharmacology 379, 381 (2008).

32. Pasricha et al., supra note 19, at 139.

33. Id. at 138. "Off label" use refers to the practice of prescribing medications for unapproved indications.

34. Id.

35. Id. at 381

36. Id.

37. Pasricha et al., supra note 19 , at 141 .

38. Id. at 143 .

39. Linda Ganzini et al., The Prevalence of Metoclopramide-Induced Tardive Dyskinesia and Acute Extrapyramidal Movement Disorders, 153 Archives of Internal Medicine 1469 (1993); see also J. Jankovic, Tardive Syndromes and Other Drug-Induced Movement Disorders, 18 CuIN. Neuropharmacology 197 (1995); L.G. Miller \& J. Jankovic, Metoclopramide-Induced Movement Disorders: Clinical Findings With a Review of the Literature, 149 ARCHIVES OF InTERNAL MEDICINE 2486 (1989).
} 
2001. See, e.g., Physicians' Desk Reference 2713-16 (55th ed. 2001). No other PDR monograph for any metoclopramide product, brand name or generic, has appeared for any year. In Conte, the crux of plaintiff's argument rested on the premise that Wyeth could have, but ultimately failed to, warn of the true association between metoclopramide and tardive dyskinesia post-FDA approval without running afoul of the FDCA and FDA regulations.

\section{Foster V. American Home Products Corporation-The Land BEFore CONTE}

Prior to the Conte decision, most courts in the country who examined the issue of brand name liability aligned themselves with a case from the United States Court of Appeals for the Fourth Circuit, Foster v. American Home Products Corporation. Applying Maryland law, the Foster court affirmed a lower district court ruling which held that the brand name manufacturer of Phenergan ${ }^{\circledR}$ (promethazine) owed no duty to warn users of the equivalent generic product of dangers associated with the medication. ${ }^{40}$

In that case, the Fosters, whose daughter died from taking the generic form of Phenergan, brought suit against the drug's pioneer. Although the district court granted the pioneer's motion for summary judgment on the products liability claims because it had not manufactured the drug, it allowed the Fosters to proceed on a claim for negligent misrepresentation, which was later dismissed for a failure to show reliance. ${ }^{41}$

As noted by the court, Maryland law requires a plaintiff to prove that the product in question was defective or in a defective condition, attribute that product to a "seller" and prove that the defect proximately caused plaintiff's injury. ${ }^{42}$ This is known as "product identification." 43 Like many states, Maryland recognizes the existence of defect claims based upon

40. Foster v. American Home Products Corporation, 29 F.3d 165 (4th Cir. 1994). Though the Foster decision involved a question of state law from Maryland, other decisions from around the country are in accord. See John and Jane Doe 2 v. Ortho-Clinical Diagnostics, Inc., 335 F. Supp. 2 d 614 (M.D.N.C. 2004) (dismissing claims against Eli Lilly \& Co., who held original patent for thimerosal, for injuries suffered by their minor child from the vaccine of another manufacturer who copied the Lilly patent under North Carolina law).

41. Foster, 29 F.3d at 167.

42. Loh v. Safeway Stores, Inc., 422 A.2d 16, 23 (Md. 1980).

43. In Conte, the court quickly distinguished cases cited by Wyeth arguing a similar requirement in California courts by noting they applied only in products liability theories, and not in negligent misrepresentation. Conte, $168 \mathrm{Cal}$. App. 4th at 101-02. 
manufacturing, design and failure to warn defects. ${ }^{44}$ However, in Foster, the appellate court noted that there were no recognized causes of action against manufacturers for injuries arising from another manufacturer's product. ${ }^{45}$

Therefore, the Foster court viewed the parents' misrepresentation claim as an attempt to circumvent Maryland's product identification requirement. ${ }^{46}$ The court held that the pioneer owed no duty of care to the Fosters whatsoever even though the Fosters had alleged it was foreseeable to the pioneer that statements contained in its label could result in injury to generic users. In describing the scope of any duty owed, the court refused to "stretch the concept of foreseeability too far" and held that a pioneer or innovator had no duty to generic patients because, in substance, they had no "right to rely" upon instructions from the maker of the brand name drug. ${ }^{47}$

The court also noted that its decision did not leave plaintiffs like the Fosters without a remedy against generic manufacturers even though they had not been involved in the approval of the original label. The court argued that generic manufacturers could "add or strengthen a contraindication, warning, precautions or adverse reaction" or "delete false, misleading or unsupported indications for use or claims for effectiveness" without having to obtain FDA approval for such changes under the FDCA's "Changes Being Effected" provisions, located at 21 C.F.R. $\S \S 314.70(\mathrm{c})(2)$ and $314.97 . .^{48}$ Further, the court rejected the notion that a generic manufacturer could not be liable for misstatements in its label despite not having created any of those misstatements, instead holding it to the knowledge and skill of an expert on the product. ${ }^{49}$ Thus, in Foster's view, although both manufacturers-pioneer and generic alike - must warn about risks of which they either knew of or should have known of, each can only be liable to plaintiffs who ingest their respective products, even in instances where the labels remain identical. ${ }^{50}$

44. Klein v. Sears, Roebuck \& Co., 608 A.2d 1276, 1280 (Md. 1992); Phipps v. General Motors Corp., 363 A.2d 955, 959 (Md. 1976); Moran v. Faberge, Inc., 332 A.2d 11 (Md. 1975).

45. Foster, 29 F.3d at 168.

46. Id.

47. Id. at 171 .

48. Id. at 169 .

49. Id.; Barson v. E.R. Squibb \& Sons, Inc., 682 P.2d 832, 835 (Utah 1984). See also Erickson v. Baxter Healthcare, Inc., 151 F. Supp. 2d 952 (N.D. Ill. 2001).

50. Barson, 682 P.2d at 836. Specifics of what the manufacturer knew or should have known and what was known in the medical community are questions of fact, rather than law, and are to be established through expert testimony. James T. O’Reilly, Food and Drug Administration 9 (3d ed. 2007). 
Following Foster, a number of courts adopted its reasoning as decisive of innovator liability. ${ }^{51}$ After all, its logic seemed appealing — why should a manufacturer of one product be liable for injuries caused by another? For instance, in Colacicco v. Apotex, Inc., the District Court for the Eastern District of Pennsylvania dismissed an action against GlaxoSmithKline ("GSK"), the brand name manufacturer of Paxil ${ }^{\circledR}$ (paroxetine hydrochloride), on grounds of preemption and for lack of any duty owed to users of its generic equivalent. $^{52}$ The plaintiff alleged that the medication caused his wife to commit suicide in her home some 22 days after ingesting the anti-depressant. ${ }^{53}$ Relying heavily on Foster for the basis of its opinion, the Colacicco court distinguished Foster's reliance on foreseeability as the main determinant in duty from Pennsylvania's "more nuanced" approach involving public policy. ${ }^{54}$ This decision seemed to add yet another argument in favor of Foster. With respect to public policy, considerations included the societal importance of encouraging the development of new and effective prescription drugs and of

51. These include Mensing v. Wyeth, Inc., No. 07-cv-03919 (DWF/SRN), 2008 WL 4724286, at *5 (D. Minn. 2008); Buchanan v. Wyeth Pharms., Inc., CV-2007-900065, slip. op. at 1 (Ala. Cir. Ct. 2008); Westerlund v. Wyeth, Inc., No. MID L02174-05, slip op. at 3 (N.J. Super. Ct. 2008); Smith v. Wyeth, Inc., No. 5:07-CV-18-R, 2008 WL 2677051, at*4 (W.D. Ky. 2008); Wilson v. Wyeth, Inc., No. 3:07-CV-378-R, 2008 WL 2677049, at*4 (W.D. Ky. 2008); Morris v. Wyeth, Inc., No. 1:07-CV-176-R, 2008 WL 2677048, at *4 (W.D. Ky. 2008); Stanley v. Wyeth, Inc., 991 So. 2d 31, 34 (La. App. 2008); Pustejovsky v. Wyeth, Inc., No. 4:07-CV-103-Y, 2008 WL 1314902, at*2 (N.D. Tex. 2008); Swicegood v. Pliva, Inc., 543 F. Supp. 2d 1351, 1358-59 (N.D. Ga.); Green v. Wyeth Pharms., Inc., CV-06-3917 ER, slip. op. at 1 (Ala. Cir. Ct. 2007); Barnhill v. Teva Pharms. USA, Inc., No. Civ. A. 06-0282-CB-M, slip. op. at 4 (S.D. Ala. 2007); Leblanc v. Wyeth, Inc., No. Civ. A 04-0611, 2006 WL 2883030, at *6 (W.D. La. 2006); Goldych v. Eli Lilly and Co., No. 5:04CV1477, 2006 WL 2038436, at *3-*6 (N.D.N.Y. 2006); Colacicco v. Apotex, Inc., 432 F. Supp. 2d 514, 540-41 (E.D. Pa. 2006), aff'd, 521 F.3d 253 (3d Cir. 2008); Sharp v. Leichus, No. 2004-CA-0643, 2006 WL 515532, at *4 (Fla. Cir. Ct. 2006), aff'd per curiam, 952 So. 2d 555 (Fla. App. 2007); Tarver v. Wyeth, Inc., No. Civ. A. 3-04-2036, 2005 WL 4052382, at *2 (W.D. La. 2005); Kelly v. Wyeth, No. CIV.A.MICV200303314B, 2005 WL 4056740, at *2 (Mass. Super. Ct. 2005); Reynolds v. Anton, No. 01A-76719-3, 2004 WL 5000272, at 9 (Ga. Super. Ct. 2004); Sheeks v. Am. Home Prods. Corp., No. 02CV337, 2004 WL 4056060, at *2 (Colo. Dist. Ct. 2004); Sloan v. Wyeth, No. MRS-L-118304, slip op. at 5 (N.J. Super. Ct. 2004); Block v. Wyeth, Inc., No. CIV.A. 3:02-CV-1077, 2003 WL 203067, at *2 (N.D. Tex. 2003); Flynn v. American Home Prods. Corp., 627 N.W.2d 342, 350 (Minn. Ct. App. 2001); Beutella v. A.H. Robins Co., Inc., No. 05-CV-2372, 2001 WL 35669202, at *2 (Utah Dist. Ct. 2001).

52. Colacicco v. Apotex, Inc., 432 F. Supp. 2d 514 (E.D. Pa. 2006), judgment aff'd, 521 F.3d 253 (3d Cir. 2008), cert. granted, judgment vacated, 129 S. Ct. 1578 (2009).

53. Paxil belongs to a class of drugs known as Selective Serotonin Reuptake Inhibitors ("SSRIs"). SSRIs are used by physicians for the treatment of depression and anxiety. On June 30, 2005, the FDA issued a public health advisory warning of the potential for SSRIs to cause suicidal thoughts and behaviors in patients on the medication. Id. at 519 n.2; see also FDA Public Health Advisory, Suicidality in Adults Being Treated with Antidepressant Medications (June 30, 2005), http://www.fda.gov/cder/drug/advisory/ SSRI200507.

54. Colacicco, 432 F. Supp. 2d at 539-43. 
showing deference to the FDA as being uniquely qualified to determine matters of drug policy and to decide labeling matters. ${ }^{55}$ Of course, this deference in the latter part of the opinion was no doubt guided by the court's acceptance of a preemption argument, which, on appeal, was remanded by the Supreme Court following its decision in Wyeth v. Levine. ${ }^{56}$ But, the Colacicco court-like Foster-refused to extend liability to the brand name manufacturer when the plaintiff's wife had only ingested the generic version of the drug.

With the handwriting on the wall, the generic manufacturers in Colacicco tried to distance themselves from Foster by arguing that since they were no longer parties in Foster at the time the opinion was delivered, that the court's imposition of a duty on their part for labeling inaccuracies was merely dicta. The Colacicco court did not agree. Rather, it relied upon Foster's reasoning as persuasive, adopting it to create a duty on the part of the generic manufacturer..$^{57}$ "Apotex [the generic manufacturer] is still a business, manufacturing drugs ... not for some altruistic reason, but to realize a profit. Apotex reaps the financial rewards ... and it cannot hide from liability by crying regulatory foul. ${ }^{.58}$ The court did not believe it economically unfair to impose that duty on Apotex, as it is one imposed on manufacturers of any product. ${ }^{59}$ Thus, Colacicco like Foster, likely implies that the economic benefit generic manufacturers stand to gain from the sale of generic medications is sufficient to levy liability against them for labeling deficiencies regardless of the source of those deficiencies.

However, the importance of Colacicco's interpretation of Pennsylvania law may be limited, as its reasoning was later rejected in Clarkv. Pfizer, Inc. ${ }^{60}$ In Clark, the state court decided that under Pennsylvania law, the brand name manufacturer of the drug Neurontin ${ }^{\circledR}$ (gabapentin) could be liable for misrepresentations to foreseeable plaintiffs in an off-label use case even though there was no direct relationship between them, applying the same nuanced policy factors from Colacicco. The court noted:

(1) The relationship between the purchasers of generic Gabapentin and these defendant manufacturers . . . which would never have been purchased but for defendant's massive advertising campaign of misrepresentation.

55. $I d$.

56. Colacicco v. Apotex, Inc., 129 S. Ct. 1578, 1579 (2009).

57. Colacicco, 432 F. Supp. $2 d$ at 544.

58. Id.

59. Id.

60. Clark v. Pfizer, Inc., No. 1819, 2008 Phila. Ct. Comm. Pl. LEXIS 242 (2008). 
(2) Social Utility: There is no social utility to the defendant's conduct, namely the misrepresentation of scientific knowledge broadcast through conferences, manipulation of medical data, medical literature and consulting contracts to promote junk-science.

(3) The nature of the risks imposed is the use of medications for which no scientific proof of effectiveness has ever occurred; and the foreseeability of the harm, namely purchased no more productive than placebo treatment was the intention of the advertising campaign.

(4) The consequences of imposing a duty upon the defendants . . nothing greater than the requirement that pharmaceutical advertising of drugs and promotion be in accord with scientific knowledge and Federal law rather than market requirements and profitability concerns.

(5) The overall public interest in the proposed solution that pharmaceutical companies be required to obey the FDCA and only promote drugs for approved uses or foster medical discussion for scientifically proven uses is the most salutary result possible. ${ }^{61}$

\section{Drug Policy, Approvals and Labeling Concerns}

\section{A. Brand Name v. Generic Policy}

Although Conte and Foster differ in their approaches and conclusions regarding innovator liability, the difference is based on more than just variations of state law. Instead, in the difference is one of policy, based on numerous factors, including: (1) the value of innovation placed upon drug development by the reviewing court; (2) the extent to which the court views the role of a generic competitor; (3) the continuing role and obligations of vigilance over a drug's label; and (4) the lens through which the court views foreseeability. The proper weight to be assigned these factors by a court requires more understanding of the generic pharmaceutical business than either opinion provides.

Generic medications cost much less than their brand name counterparts. ${ }^{62}$ Virtually every segment of our health care system promotes generics over brand names, except, of course, for pharmaceutical companies that research and develop brand name drugs. Indeed, many states have laws that require pharmacists to fill prescriptions with generic medications when available and when not restricted by a physician's orders. ${ }^{63}$ Consumers have grown more

61. Id. at *24-28; see also Rebecca Porter, Courts Disagree on Who's Liable for Generic-Drug Injuries, 45 Trial 14, 26 (Feb. 2009).

62. Generic Pharmaceutical Association, Facts at a Glance (2009), http://www.gphaonline.org/ aboutgpha/about-generics/facts [hereinafter Facts at a Glance].

63. Jeffrey R. Pilkington \& Shannon Wells Stevenson, Whose Label Is It Anyway? Liability for Injuries Caused by Generic Prescription Drugs, In-House Defense Q. 44, 45 (Winter 2007). 
price conscious over the years, especially the elderly whose prescription drug bills often compete with other necessities for living. ${ }^{64}$ Today, pharmacies market a menu of low cost prescriptions, and insurers require a much lower co-pay for generics than for brand name drugs. ${ }^{65}$ At every level, there is an incentive to choose the generic over the higher cost alternative. But in some cases, a generic is not yet available as the exclusive period in which a manufacturer has to market its brand name drug has not expired.

This exclusivity, representative of a protected monopoly, is based upon a very reasonable policy decision: that is, to encourage research and development of new medications. After all, there are numerous reasons to protect the investments made by brand name pharmaceutical manufacturers in drug innovation. First, research and development of new medications is incredibly expensive. On average, it takes approximately ten to fifteen years of research to develop a new medication, with each approval costing about $\$ 800$ million. ${ }^{66}$ For every 5,000 to 10,000 new drug compounds tested, only 250 will enter preclinical testing, and only 5 will enter clinical trials. ${ }^{67}$ In the end, out of the 5,000 to 10,000 compounds tested by a sponsor, FDA may only approve one for marketing. ${ }^{68}$ In 2005, the pharmaceutical industry invested some $\$ 51.3$ billion in research and development costs to study new drugs. ${ }^{69}$ This enormous investment and expense is directly responsible for what provides physicians with the ability to fight diseases and treat conditions that were once considered to be life-threatening.

In recognition of the costly nature inherent in drug development, Congress gave the pharmaceutical manufacturers a period of exclusivity ${ }^{70}$ following FDA approval in which they could market and sell their drugs without fear of competition. Once the period of exclusivity concludes, generic manufacturers enter the market essentially copying the drug and selling the medication at substantial discounts. It is far beyond the scope of this article to determine whether that policy should also ensure blockbuster profits for brand name manufacturers and for how long. However, it is sufficient to recognize

64. Jane Sarasohn-Kahn, The Wal-Martization of Healthcare: The Growing Role of Value for Consumers, THINK-Health (Nov. 2006), http://gfk-pipeline.com/pipeline/2006/november/ topline_11_06_walmart.html

65. $\quad \bar{I} d$.

66. Pharmaceutical Research and Manufacturers of America, Pharmaceutical Industry Profile 2006, at 2 (2006) [hereinafter PhRMA Profile].

67. Id. at 5 .

68. Id. at 2 .

69. $I d$.

70. See O'ReILly, supra note 50, at 3-29. 
that once a manufacturer loses its exclusivity, it also loses its revenue stream for that product almost entirely. Thus, exclusivity allows the pioneer to recoup the costs of research and development and earn a reasonable profit by giving the manufacturer a time period of exclusive sales while barring the FDA from approving entry of a generic competitor.

To some, including the Foster and Colaccio courts, generic manufacturers are viewed as scavengers. ${ }^{71}$ They merely lie in wait for a drug to near the end of its exclusivity and then they file an Abbreviated New Drug Application ("ANDA") with the FDA to allow them to market a drug that is considered as a "bioequivalent" to the pioneer. ${ }^{72}$ In effect, the generic manufacturer is allowed to then ride the coattails of the pioneer. ${ }^{73}$ And, because the FDA does not require any additional research as part of the ANDA, the generic manufacturer typically does not conduct clinical trials apart from those submitted to the FDA in the original sponsor's New Drug Application ("NDA"). Thus, the generic manufacturer is generally able to sell a copy of the drug for whatever it costs to manufacture it.

Because of the relative ease with which a generic manufacturer is able to enter the pharmaceutical market as opposed to that of an innovator, generic drug manufacturing is a very successful business. This is true even despite what is sometimes a huge price differential between a generic and brand name version. For example, in 2007, generic prescriptions accounted for 69 percent of all prescriptions dispensed in the United States, representing some 2.6 billion prescriptions. ${ }^{74}$ The average retail price of a generic drug that year was $\$ 34.34$ compared to the average brand name price of $\$ 119.51 . .^{75}$ Nearly $79 \%$ of all of the drugs listed in the FDA Orange Book today have generic equivalents. ${ }^{76}$ In the future, the generic drug industry is expected to grow faster than the brand name industry in part due to increasingly cost-conscious patients and research manufacturers' shrinking drug pipeline. ${ }^{77}$

71. See Foster, 29 F.3d at $169-70$.

72. 21 U.S.C. $\S 355(\mathrm{j})(2)(\mathrm{A})$.

73. Munroe v. Barr Laboratories, 670 F. Supp. 2d 1299, 1303 (N.D. Fla. 2009).

74. Facts at a Glance, supra note 62.

75. Id.

76. Id. The Orange Book, as it is called, contains the list of "Approved Drug Products With Therapeutic Equivalence Evaluations," listing a series of names of drug products and patents asserted by the patent owners to protect those from generic competitors. O'REILLY, supra note 50, at 13-203.

77. $I d$. 


\section{B. Regulatory Approval of New Drugs}

The FDCA prohibits persons from introducing any "new drug" into interstate commerce that has not been approved by the FDA pursuant to 21 U.S.C. $\S 355 .{ }^{78}$ Before researchers may begin testing a new drug in human subjects, the manufacturer or sponsor must submit an Investigational New Drug ("IND") application to the agency for approval. ${ }^{79}$ To protect human subjects against unreasonable risks, the IND contains laboratory findings and the results of animal studies. ${ }^{80}$ If the FDA approves the IND, the sponsor then moves on to three phases of clinical trials. ${ }^{81}$ In Phase I, the medication is tested in a small group of subjects to determine safety and acceptable dosage, typically numbering 20 to 100 volunteers. ${ }^{82}$ From there, Phase II studies proceed with roughly 100 to 500 volunteers in controlled trials to determine efficacy. ${ }^{83}$ During this time, researchers continue to monitor for safety, side effects and optimal dosage. ${ }^{84}$ In Phase III, 1,000 to 5,000 volunteers are enrolled in clinical trials to take the medication with researchers monitoring for safety, efficacy and side effects against a comparator-a placebo ${ }^{85}$ The time required to complete all three phases of clinical trials presently averages 8.6 years. ${ }^{86}$

Assuming that the trials demonstrate safety and efficacy, the sponsor will then file an NDA with the agency, containing results from the clinical testing, as well as the content of the proposed label.$^{87}$ Usually, an NDA includes more than 100,000 pages of data for the agency to review which contains the following: ${ }^{88}$

A. full reports of investigations which have been made to show whether or not such drug is safe for use and whether such drug is effective in use;

B. a full list of the articles used as components of such drug;

C. a full statement of the composition of such drug;

78. 21 U.S.C. $\$ 355(a)$. Note these requirements are only imposed on "new drugs" as defined by 21 U.S.C. $\S 321(\mathrm{p})$, and not those subject to the FDCA prior to 1938 .

79. See 21 C.F.R. pt. 312 and 48 Fed. Reg. 26720 (June 9, 1983).

80. PhRMA Profile, supra note 66 , at 5.

81. Id.

82. Id.

83. Id.

84. $I d$.

85. Id.

86. $I d$.

87. $I d$.

88. 21 U.S.C. $\S 355(b)(1)$. 
D. a full description of the methods used in, and the facilities and controls used for, the manufacture, processing, and packing of such drug;

E. such samples of such drug and of the articles used as components thereof as the Secretary may require;

F. specimens of the labeling proposed to be used for such drug, ...; and

G. any assessments required under section $355 \mathrm{c}$ of this title.

21 U.S.C. $\S 355(\mathrm{~b})(1)$. By way of comparison, the requirements for an Abbreviated New Drug Application can be found in 21 U.S.C. § 355(j)(2)(A).

FDA must approve the NDA unless the proposed new drug fails to meet certain criteria, including whether clinical testing data and other information show that the drug is safe and effective for "use under the conditions prescribed, recommended, or suggested in the proposed labeling" and whether "based on a fair evaluation of all material facts, [its] labeling is false or misleading in any particular." 89 The FDA often uses independent advisory committees to consider the evidence and to vote on whether a new drug should be approved for marketing. ${ }^{90}$ Approximately 10 to 15 percent of drugs are rejected during this NDA review. ${ }^{91}$ In 2008, the FDA approved a total of 24 new medications, the most in three years. ${ }^{92}$

\section{1984: A Compromise in the Making-The Hatch-Waxman Amendments to the FDCA ("Hatch-Waxman")}

The decade of the 1980s saw increasing regulatory and fiscal pressures on government, particularly for the Department of Health \& Human Services. ${ }^{93}$ These pressures included competing calls for lowering the price of prescription drugs while increasing the safety and efficacy of drugs by highly regulating drug manufacturing. ${ }^{94}$ At the same time, a related concern surfaced growing out of the 1962 amendments to the FDCA. Those amendments had imposed a new requirement on drug approvals, that of demonstrating efficacy. ${ }^{95}$ This requirement slowed down the agency's approval process

89. Id. 21 U.S.C. $\S 355(\mathrm{~d})$.

90. PhRMA Profile, supra note 66, at 5.

91. Id.

92. Matthew Herper, The Value of New Drugs Is Dropping, Forbes.com (Jan. 8, 2009), http://www.forbes.com/2009/01/07/pharmaceuticals-sales-biz-healthcare-cx_mh_0108drugssales.html.

93. O'ReILLY, supra note 50, at 3-28.

94. Id.

95. Allan M. Fox \& Alan R. Bennett, The Legislative History of the Drug Price Competition and Patent Restoration Act of 1984, Food and Drug Law Institute Series (1987) (Foreword). 
considerably, extending the time it took to grant approval of an application. ${ }^{96}$ By the time the drug eventually gained approval, manufacturers lost substantial time in their patent exclusivity period. ${ }^{97}$ At the same time, as NDAs became more complex and required more review for the brand name manufacturers, the same requirements adversely affected development of generic drugs. ${ }^{98}$

Following several studies and debates, a consensus also emerged recognizing the fact that generic medications successfully hold down overall drug costs. ${ }^{99}$ But, it was not a consensus generated by public outcry, proconsumer groups or even the very Congressmen who would ultimately champion the proposed legislation that would ease the entry of generic medications to market. ${ }^{100}$ Rather, two competing economic groups within the pharmaceutical industry forged this consensus: the research manufacturers and their generic counterparts. ${ }^{101}$ These two groups worked side by side and developed a compromise, signing on key Senate and House members who took the helm of the legislation. ${ }^{102}$ Key Congressmen included House Democrat Henry Waxman of California and Republican Senator Orrin Hatch of Utah, after whom the bill was named. ${ }^{103}$

As a result, the Hatch-Waxman bill provided for an abbreviated avenue for generic manufacturers to come to market by relying upon the information contained in the manufacturers' original NDAs. ${ }^{104}$ In exchange for relieving generic manufacturers of providing clinical data, FDA would now extend the period of market exclusivity for pioneer manufacturers. ${ }^{105}$ Consequently, Hatch-Waxman was promoted as a compromise bill between these two competing industries. ${ }^{106}$

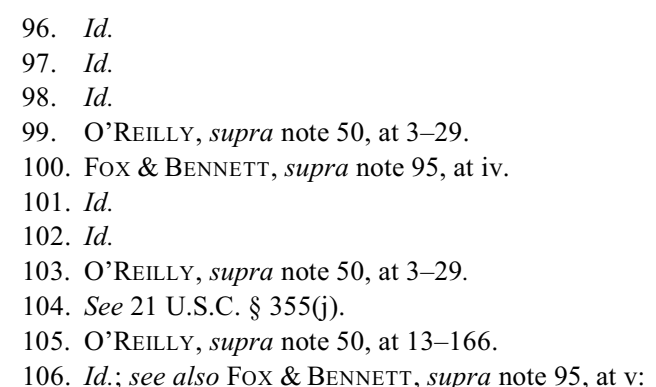

Each minor change in the legislation had a significant impact on one side or the other so that each change had to be carefully balanced. One indication of the controversial nature and sensitivity of the coalition was that there is almost none of the usual legislative history to this bill. There are no Senate reports, for example, and floor statements were extremely limited and dealt with only a small number of technical points. To really understand the intent of this legislation, one almost had to be there as it was negotiated. 
Normally, federal patent laws provide inventors with a patent term of 20 years in which they can exclusively sell their invention. ${ }^{107}$ However, with pharmaceuticals, it may take 10 to 15 years to bring a drug to market. ${ }^{108}$ The pharmaceutical industry estimates that, on average, the average "effective patent life" for medications is 11.5 years. ${ }^{109}$

After a brand name, NDA-approved drug loses its patent protection, a generic manufacturer may file an ANDA, seeking FDA approval to market a generic version of the brand name drug. ${ }^{110}$ Prior to 1984 , if a generic manufacturer desired to market its generic version of the drug, it had to submit an NDA just like the manufacturer, showing evidence of safety and efficacy. ${ }^{111}$ After Hatch-Waxman, to receive ANDA approval, a generic manufacturer need not submit independent evidence of the drug's safety and efficacy; it need only establish the generic product's "bioequivalence" to the brand name listed drug. ${ }^{112}$

As discussed elsewhere, the labeling under the ANDA must be identical to that used with the brand name drug. ${ }^{13}$ After FDA approves an ANDA, the manufacturer is subject to most of the same statutory and regulatory obligations as the brand name manufacturer, including the obligation to keep its label current. Otherwise, the product might be considered misbranded under 21 U.S.C. $\S 352 .{ }^{114}$

As soon as Hatch-Waxman implemented the generic approval process, literally hundreds of abbreviated drug applications funneled through the agency. ${ }^{115}$ Many companies fresh to the highly regulated pharmaceutical industry and many from outside the United States began to compete for the lucrative business of manufacturing generics. ${ }^{116}$ Understandably, much of the early focus on generics was generated by the growth of the market following Hatch-Waxman and was not devoted to more developed and complex questions such as the interplay with products liability. In fact, the legislative

107. PhRMA Profile, supra note 66, at 7.

108. Id. at 8 .

109. $I d$.

110. See 21 U.S.C. $\S 355(\mathrm{j})$.

111. Pilkington \& Stevenson, supra note 63, at 45.

112. Id. Generally, a drug is bioequivalent to another if its bioavailability (the rate and extent to which its active ingredients are absorbed to the treatment site) does not differ significantly from the bioavailability of those ingredients in the brand name product. See 21 U.S.C. $\S 355(\mathrm{j})(8)(B) ; 21$ C.F.R. $\S 320.1(\mathrm{e})$. Thus, a drug with an approved ANDA is therapeutically identical to the brand name drug.

113. Id. 21 U.S.C. $\S 355(\mathrm{j})(2)(\mathrm{A})(\mathrm{v})$.

114. See 21 U.S.C. $\S \S 352(a) ; 355(j)(2)(A)(i i i)-(i v),(4) ; 21$ C.F.R. $\S \S 314.105(d), 314.127$.

115. O'ReILly, supra note 50, at 3-30; see also FoX \& BENNETT, supra note 95, at v-vi.

116. O'ReILly, supra note 50, at 3-30. 
history for the act does not contain any signal that either brand name or generic manufacturers ever considered its liability implications. To some, that lack of discussion may be seen as a reason not to impose liability for a generic product onto an innovator. However, to others, it represents a conscious decision by the research manufacturers to allow generic manufacturers to obtain quick approvals by copying their drugs in return for a negotiated position and longer period of market exclusivity. Suggesting that the position enjoyed by generics is merely one of copying and scavenging for profit, as Foster implies, ignores the very economic forces that created Hatch-Waxman.

Today, admittedly, some critics could question the success of the HatchWaxman amendments to the FDCA, as low-cost generics have become widely available while overall expenditures on prescription drugs have steadily increased, being on par to the increases seen just prior to enactment of HatchWaxman. For instance, in 2007, Americans spent more than $\$ 227$ billion on prescription drugs, an increase of $4.9 \%$ over 2006 expenditures. ${ }^{117}$ Comparatively, in 1984, Americans spent only $\$ 19.6$ billion on prescription drugs. ${ }^{118}$

Since Hatch-Waxman was passed, increases in year-over-year drug spending have ranged from last year's low of $4.9 \%$ to a high of $18.14 \%$ in 1999. These numbers compare to annual increases of $1.57 \%$ (1961) to $15.26 \%$ (1983) in the 20 years prior to the legislation. ${ }^{119}$ While there is anecdotal evidence of the impact of generics on seniors and the uninsured as they rely on low cost prescriptions instead of expensive brand names, it appears that efforts at keeping health care costs associated with pharmaceuticals in check have proved unsuccessful. Although drug expenditures occupy only a small portion of the total amounts spent on health care, it is one of the fastest growing components. ${ }^{120}$ In 2006, the annual rate of increase in spending was $9 \%$ for prescription medications, compared to $7 \%$ in hospital care and $6 \%$ in physician services. ${ }^{121}$

A recent watchdog report from the American Association of Retired Persons found that brand name manufacturers raised prices on prescription drugs far in excess of price increases for other consumer goods during the last

117. National Health Expenditures by Type of Service and Source of Funds, CY 1960-2007, Centers for Medicare and Medicaid Services (2009), http://www.cms.hhs.gov/NationalHealthExpendData/ 02_NationalHealthAccountsHistorical.asp\#TopOfPage.

118. $I d$.

119. $I d$.

120. Kaiser Family Foundation, Prescription Drug Trends, Sept. 2008.

121. Id. 
year. ${ }^{122}$ The report found that prices of brand name prescriptions used most widely by Medicare beneficiaries increased by 9.3 percent in the 12 months ending with September 2009, an increase much higher than the rate of increase observed during any of the prior seven years (i.e., 2002 to 2008). ${ }^{123} \mathrm{In}$ contrast, the report noted that the average price of generic drugs fell by 8.7 percent for the same period. ${ }^{124}$ So, while the legislation has increased the number of generic medications available, it seems to have had little effect on controlling overall prescription drug costs.

\section{Duties Accompanying Drug Labels}

Once a brand name drug or generic is approved by FDA, it must be labeled in an approved form. ${ }^{125}$ Because drug labels provide information to be used by physicians in prescribing and administering an approved drug, FDA's regulations detail the proper form and content for labeling. ${ }^{126}$ As required, a

122. Data current through September 30, 2009. Stephen W. Schondelmeyer, Leigh Purvis \& David J. Gross, Rx Watchdog Report: Drug Prices Continue to Climb Despite Lack of Growth in General Inflation Rate, Insight on the Issues (Nov. 17, 2009), http://assets.aarp.org/rgcenter/ppi/health-care/i36watchdog.pdf. Drug prices for the top 25 prescribed drugs ranged from a low of $4.8 \%$ (Protonix ${ }^{\circledR}$, manufactured by Wyeth) to $19.7 \%$ (Flomax ${ }^{\circledR}$, manufactured by Boehringer Ingelheim) over the prior year.

123. Id. Other findings include:

- The average annual cost for one brand name medication was about $\$ 2,045$ in the 12 months ending with the third quarter of 2009 . The average annual cost to a consumer taking three brand name medications during this 12 -month period was $\$ 6,134$.

- For a consumer who takes three brand name prescriptions on a chronic basis, the average annual increase in cost of therapy for brand name medications rose by $\$ 605$ for the year ending in September 2009, compared to an increase of $\$ 540$ in 2008.

- 96 percent (210 of 219) of the brand name drug products experienced a price increase in the 12 month period (i.e., October 2008 through September 2009).

- Nine (4 percent) of the 219 brand name drug products had no change in price during the same period.

124. $I d$. Other findings include:

- The average annual cost for one generic medication was $\$ 312$ in the 12 months ending with the third quarter of 2009. The average annual cost to a consumer taking three generic medications during this 12 month period was $\$ 937$.

- For a consumer who takes three generic prescriptions on a chronic basis, the average cost of therapy decreased by more than $\$ 63$ in the 12 months ending with the third quarter of 2009 , compared with nearly $\$ 52$ in 2008.

- On average, prices for the 185 generic drug products most widely used by Medicare beneficiaries fell by 8.7 percent in the 12 months ending with the third quarter of 2009 . This represented a slowdown from 2008 , when manufacturer prices for widely used generic drugs fell by 11.2 percent.

125. See 21 C.F.R. $\S 314.70(b)(2)(v)$.

126. See generally 21 C.F.R. pt. 201. 
prescription drug will be accompanied by a label, often referred to as a "package insert," which includes drug indications, contraindications, instructions for use, warnings and similar information. This prescription drug information also appears in the Physicians' Desk Reference ("PDR"). ${ }^{127}$ A PDR entry, or monograph, consists verbatim a product's FDA-approved labeling. ${ }^{128}$ Drug companies typically pay for PDR publication for their brand name drugs, but not for generic drugs. ${ }^{129}$ Doctors often rely on the PDR for information to obtain necessary information about drug indications, contraindications, warnings, proper dosage and administration, and the like. ${ }^{130}$

However, a label's content is not permanent or set in stone. In certain circumstances, a manufacturer is required to alter its labeling. FDA regulations provide that approved drug "labeling shall be revised to include a warning as soon as there is reasonable evidence of an association of a serious hazard with a drug." ${ }^{\prime 131}$ Necessary label changes are generally made through a "supplement" submitted by the manufacturer to FDA. ${ }^{132}$ Indeed, manufacturers are permitted to revise labels without prior FDA approval "to add or strengthen a contraindication, warning, precaution, or adverse reaction; [and to] add or strengthen an instruction about dosage and administration that is intended to increase the safe use of the drug product." ${ }^{133}$ Thus, a manufacturer may revise a label to warn about hazards not on the current label and, indeed, must attempt to do so whenever there is reasonable evidence of an association between a drug and a serious hazard.

Despite oversight by the FDA and the demanding regulations associated with drug labeling, a manufacturer is not shielded from tort liability simply because the FDA approves its label. ${ }^{134}$ Although the industry consistently

127. Morlino v. Medical Center of Ocean County, 684 A.2d 944, 945 n.1 (N.J. Super. 1996).

128. See Physicians' Desk Reference (61st ed. 2007) (Foreword) (noting that PDR includes FDAlabeling verbatim, and same type set, capital lettering, boldface, and italics).

129. See id. (noting that PDR is published "in cooperation with participating manufacturers").

130. As Thompson puts it, "PDR is considered the standard prescription drug reference and can be found in virtually every physician's office, hospital, and pharmacy in the United States. In fact, nine out often doctors consider PDR their most important drug information reference source." See https://estore.thomsonlearning.comtl1/en/US/storefront/pdr.

131. Id. 21 C.F.R. $\S 201.80$ (e) (emphasis added).

132. See generally id. at $\S 314.70,314.71,314.90$.

133. Id. $\S 314.70(\mathrm{c})(6)(\mathrm{iii})(\mathrm{A}),(\mathrm{C})$; the regulation authorizing manufacturers to change their labels without FDA pre-approval is called the "changes being effected," or CBE, regulation, and a manufacturer's submission of a label change to FDA is called a "CBE supplement." See also 44 Fed. Reg. 37434, 37447 (1979) (revised warnings may be made by various means, including label changes and "Dear Doctor" letters).

134. O'ReILly, supra note 50, at 25-26. 
argues in favor of this presumption, most courts view FDA's regulations as a "floor," not a ceiling. ${ }^{135}$ Hence, in failure to warn cases, there are usually allegations that the manufacturer became aware of substantial risks or adverse side effects but chose not to amend its label.

\section{E. The Learned Intermediary}

Because prescription medications may only be obtained with a prescription from a physician or by someone authorized to write prescriptions under a physician's supervision, many states require the manufacturer to communicate risks and benefits of a particular medication to the patient's doctor, not the patient. ${ }^{136}$ Known as the "learned intermediary," this concept views the physician as an intermediary between the purchaser and the manufacturer. ${ }^{137}$ Accordingly, the doctor will evaluate the patient's needs, assess the risks and benefits of potential medications in light of the patient's needs and susceptibilities and consider such in his or her orders. ${ }^{138}$ The manufacturer's disclosure of risks and benefits to the prescriber normally discharges whatever obligation it has to otherwise warn users of its drugs. ${ }^{139}$ Within the context of the physician-patient relationship, potential liability for a drug manufacturer is huge, as a single miscommunication with one physician could harm a large class of patients.

135. Cf. Edwards v. Basel Pharmaceuticals, 933 P.2d 298 (Okla. 1997), and In re Zyprexa Products Liability Litigation, 489 F. Supp. 2d 230 (E.D.N.Y. 2007).

136. 63A AM. Jur. 2D Products Liability $§ 1200$ (2009).

137. Id. The term was first used in the 1996 case of Sterling Drug v. Cornish, 370 F.2d 82 (8th Cir. 1966). John A. Camp \& Gary M. Pampas, The Learned Intermediary Doctrine in Florida: Courts Wrestle with Claimed Exceptions to the Doctrine in Drug and Device Litigation, 82-DEC FLA. B.J. 8 (2008).

138. Id. See Plummer v. Lederle Laboratories, 819 F.2d 349 (2d Cir. Cal. 1987); Feliz v. Hoffman-La Roche, Inc., 540 So. 2d 102 (Fla. 1989); Hall v. Merck, Sharp \& Dohme, 774 F. Supp. 604 (D. Kan. 1991); and Stone v. Smith, Kline \& French Laboratories, 447 So. 2d 1301 (Ala. 1984).

139. An exception may exist when the manufacturer communicates benefits associated with the drug through "DTC" or direct-to-consumer advertising, e.g., television spots, magazine advertisements, etc. See generally Teresa Moran Schwartz, Consumer-Directed Prescription Drug Advertising and the Learned Intermediary Rules, 46 Food Drug Cosm. L.J. 829 (1991); Tim S. Hall, Note, Bypassing the Learned Intermediary: Potential Liability for Failure to Warn in Direct-to-Consumer Prescription Drug Advertising, 2 Cornell J.L. \& Pub. PoL'y 449, 473 (1993); Perez v. Wyeth Laboratories, Inc., 734 A.2d 1245 (N.J. 1999). Drug companies have come under increasing scrutiny for their DTC advertising, both in terms of it being misleading as to the disclosure of risks and side effects and for driving up drug expenses. The industry, on the other hand, estimates that DTC advertising only accounts for two percent of the total U.S. spending on prescription drugs and amounted to $\$ 4$ billion in 2004 compared to $\$ 47.6$ billion spend on R\&D that same year. See PhRMA Profile, supra note 66, at 22. For an excellent discussion of the learned intermediary doctrine throughout the country, see State ex rel. Johnson \& Johnson Corp. v. Karl, 220 W. Va. 463 (2007). 
The learned intermediary defense is one recognized by virtually every state. ${ }^{140}$ To overcome the defense, a patient must show that the manufacturer failed to warn the physician of a risk not otherwise known to the physician and that the failure to warn was the actual and proximate cause of the patient's injury. ${ }^{141}$ An inadequate warning may also expose the manufacturer to liability. ${ }^{142}$ Consequently, the patient must normally prove that but for the inadequate warning, the prescribing physician would not have prescribed the medication. ${ }^{143}$

\section{Foreseeability-The Key to Understanding Conte}

To understand how the Conte court arrived at its decision, it is not only important to understand the independent nature of the tort of negligent misrepresentation, but also instructive to recognize that Conte was based on California law and was not an interpretation of some national precedent. Historically, California courts did not recognize negligent misrepresentation as distinct from negligence and fraud. Beginning in 1958 and continuing through the 1960s, a series of important decisions began to frame an individual action for negligent misrepresentation. First, in Biakanja v. Irving, the California Supreme Court held that a negligence action could lie despite a lack of privity between a plaintiff and defendant based on certain policy factors. ${ }^{144}$ These factors included the extent to which the transaction was intended to affect the plaintiff, the foreseeability of harm to him, the degree of certainty that the plaintiff suffered injury, the closeness of the connection between the defendant's conduct and the injury suffered, the moral blame

140. Camp \& Pampas, supra note 137.

141. 63A Am. JuR. 2D Products Liability § 1200, supra note 136.

142. Colaccico v. Apotex, Inc., 432 F. Supp. 2d 514, aff'd, 521 F.3d 253 (3d Cir. Pa. 2008), cert. granted, vacated on other grounds, 129 S. Ct. 1578 (2009); see also Giles v. Wyeth, Inc., 500 F. Supp. 2d 1063 (S.D. Ill. 2007).

143. Id. Some plaintiffs will also file suit against the prescribing physician utilizing theories of malpractice for the physician's failure to adhere to the standard of care in considering the risks and benefits associated with a medication. Similarly, some jurisdictions view the physician as an indispensable party for jurisdictional purposes in drug product cases. See, e.g., Singleton v. Airco, Inc., 80 F.R.D. 467, 470 (D.C. Ga. 1978) (dismissing case against manufacturer for plaintiff's failure to sue providers-resident defendants - in action founded upon diversity). However, naming a physician seems highly counterproductive when plaintiffs need the physician to be cooperative with the patient's attorney regarding inadequate warnings, sales tactics, e.g., aggressive detailing, etc., from the manufacturer.

144. Biakanja v. Irving, 49 Cal. 2d 647 (Cal. 1958). 
attached to the defendant's conduct and the policy of preventing future harm. ${ }^{145}$

Subsequently, in Merrill v. Buck, the same California Supreme Court held that landlords and realtors owed a duty of care to warn potential tenants of concealed dangers where it was reasonably foreseeable that injury would result without such warning. ${ }^{146}$ Then, in 1969, a California Court of Appeal officially adopted the standard set forth in Restatement $\S 311$ in Hanberry $v$. Hearst Corp., 276 Cal. App. 2d 680, 685 (Cal. App. 1969). ${ }^{147}$

Hanberry involved the claim of a consumer against the publishers of Good Housekeeping Magazine ("GHM") for having guaranteed the quality of shoes sold in its magazine under its seal of approval. The shoes turned out to be defective and caused Mrs. Hanberry to slip and fall on vinyl flooring, injuring herself. Hanberry alleged that $G H M$ was liable to her for negligently misrepresenting the quality of the shoes. The court agreed, noting that "Hearst ha[d] placed itself in the position where public policy impose[d] upon it the duty to use ordinary care in the issuance of its seal and certification of quality so that members of the consuming public who rely on its endorsement [were] not unreasonably exposed to the risk of harm." 148 The court further disregarded the requirement of privity between the party charged with the misrepresentation and the plaintiff relying instead on public policy to define the duty. ${ }^{149}$

Although Conte could be viewed appropriately as an extension of Biakanja, Merrill and Hanberry toward foreseeable consumers who sometimes lack a choice between manufacturers of the drugs they ingest, there are some important considerations in interpreting the reach of the Conte decision. First, because Conte was decided on summary judgment rather than at trial, the court noted that certain policy implications, such as the "burdens,

145. Id. at 650 .

146. Merrill v. Buck, 375 P.2d 304 (1962). Interestingly, the court considered whether the landlord's negligence relieved the realtors' negligence and the court said no, it was an issue of "concurrent causation," meaning that both parties could be liable to the same plaintiff.

147. See also CAL. CIv. CodE $\S 1710$ defining actionable deceit as:

- The suggestion, as a fact, of that which is not true, by one who does not believe it to be true;

- The assertion, as a fact, of that which is not true, by one who has no reasonable ground for believing it to be true;

- The suppression of a fact, by one who is bound to disclose it, or who gives information of other facts which are likely to mislead for want of communication of that fact; or,

- A promise, made without any intention of performing it.

CAL. Civ. Code $\S 1710$.

148. Hanberry v. Hearst Corp., 276 Cal. App. 2d 680, 684 (Cal. App. 1969).

149. Id. at 685 . 
societal consequences, cost and insurance implications," 150 were not fully explored, and the ultimate determination of Wyeth's putative liability would remain with a jury.

Secondly, and rather interestingly, the appellate court noted that during the time that Conte was taking the drug, Wyeth had assigned its rights and liabilities associated with the medication to Schwarz Pharma, Inc. ("Schwarz") in 2002. In its agreement with Schwarz, Wyeth agreed to indemnify Schwarz for an unknown amount, and so the court dispensed with further analysis. The use of such an agreement will be discussed later, as no doubt, pioneers may search for ways to "pass the buck" on future potential liability for actions of generic drug manufacturers. However, the presence of such agreement in Conte and its relegation to the "back burner," so to speak, suggests that a court may look beyond such an assignment and lay liability on the innovator for its conduct with respect to labeling as if it were a non-delegable duty.

When it comes to foreseeability, several standards have emerged throughout the country to define how far a court will go in extending foreseeability of a defendant's conduct, including (1) the "near privity" standard; (2) the foreseeability standard and (3) the Restatement standard. ${ }^{151}$

Under the near privity standard, a plaintiff must generally establish:

(1) the information provider ${ }^{152}$ must have been aware that the misinformation would be used in a specific transaction or for a specific purpose;

(2) the information provider must have known that the misinformation would be relied upon by a third party; and

(3) there must have been some conduct by the information provider linking it to the third party that evidences the providers' understanding that the third party would rely on the misinformation. ${ }^{153}$

Most third parties cannot meet the near privity standard; typically, the information provider does not directly communicate with the third party, and any conduct by the provider is not more than merely incidental or collateral to inducing reliance in the third party. ${ }^{154}$ Under this standard, there would be no innovator liability to purchasers of generic drugs since there would be no direct contact between the manufacturer and the ultimate patient. Even in

150. Conte, 168 Cal. App. 4th at 107.

151. Robert K. Wise \& Heather E. Poole, Negligent Misrepresentation in Texas: The Misunderstood Tort, 40 TeX. TeCh L. Rev. 845, 849-52 (2008).

152. The "information provider" is usually the defendant in misrepresentation and fraud cases and supplies incorrect or insufficient information to the plaintiff.

153. Id. at 849 .

154. Id. 
cases of direct-to-consumer advertising, such communication could only be described as incidental: prescription medications are only attainable under the orders of a physician, who determines independently the appropriate course of treatment for his or her patient.

Under the foreseeability standard, an information provider can be liable to any third party whose reliance on a misrepresentation is reasonably foreseeable. ${ }^{155}$ This test of reasonable foreseeability is the most expansive of the three tests. ${ }^{156}$ Arguably, the foreseeability standard is the standard that Conte relied upon to put forward its policy of innovator liability. In Conte, the court adopted Restatement (Second) $\S \S 310$ and 311 as its guide to defining what was foreseeable to Wyeth.

Section 310 provides that:

An actor who makes a misrepresentation is subject to liability to another for physical harm which results from an act done by the other or a third person in reliance upon the truth of the representation, if the actor (a) intends his statement to induce or should realize that it is likely to induce action by the other, or a third person, which involves an unreasonable risks of physical harm to the other, and (b) knows (i) that the statement is false, or (ii) that he has not the knowledge which he professes.

Restatement (Second) of Torts $\S 310$.

\section{Section 311 provides that:}

(1) One who negligently gives false information to another is subject to liability for physical harm caused by action taken by the other in reasonable reliance upon such information, where such harm results (a) to the other, or (b) to such third persons as the actor should expect to be put in peril by the action taken.

(2) Such negligence may consist of failure to exercise reasonable care (a) in ascertaining the accuracy of the information, or (b) in the manner in which it is communicated.

Restatement (Second) of Torts $\S 311$ (1965).

Notably, these sections of the Restatement lack any element of privity, extending a duty to all foreseeable persons who may be deceived or misled by the misrepresentation. These sections are also broader than the scope of liability for strictly pecuniary losses resulting from negligent misrepresentations under Section 552 of the Restatement (Second) of Torts. This is the section upon which the third standard is based and one that the majority of courts have followed. ${ }^{157}$ It states:

155. Id. at 850

156. $I d$.

157. Id. at 852 . 
(1) One who, in the course of his business, profession or employment, or in any other transaction in which he has a pecuniary interest, supplies false information for the guidance of others in their business transactions, is subject to liability for pecuniary loss caused to them by their justifiable reliance upon the information, if he fails to exercise reasonable care or competence in obtaining or communicating the information.

(2) Except as stated in Subsection (3), the liability stated in Subsection (1) is limited to loss suffered (a) by the person or one of a limited group of persons for whose benefit and guidance he intends to supply the information or knows that the recipient intends to supply it; and (b) through reliance upon it in a transaction that he intends the information to influence or knows that the recipient so intends or in a substantially similar transaction.

(3) The liability of one who is under a public duty to give the information extends to loss suffered by any of the class of persons for whose benefit the duty is created, in any of the transactions in which it is intended to protect them.

\section{Restatement (Second) of Torts $\S 552$.}

Obviously, this standard is narrower than the foreseeability standard because it limits liability to a specific transaction or to a substantially similar one of which the provider is actually aware of and of which the provider intends to influence. ${ }^{158}$ Section 552, Comment (c) clarifies that relationship by noting that liability can only arise "when the defendant has a pecuniary interest in the transaction in which the information is given." ${ }^{59}$ One might assume that this clarification would foreclose liability against the innovator as there is no pecuniary relationship between it and a purchaser of a generic medication. However, the simple fact that the innovator received no financial consideration for the generic product does not mean the innovator lacks a pecuniary interest. ${ }^{160}$

If the information, such as that that may be conveyed in a drug's label or monograph, is given in the course of the defendant's business, then a sufficient pecuniary interest would be involved, even though the defendant receives no consideration for it at the time. ${ }^{161}$ To establish a sufficient pecuniary interest, all that is needed is that the information provider must at least provide information with the expectation of some indirect pecuniary benefit, such as future business, referrals, or the abandonment or avoidance

158. $I d$.

159. Restatement (SeCOND) OF Torts $\S 552 \mathrm{cmt}$. c (1997).

160. Id. at cmt. d.

161. Id., accord Mid-States Dev., LLC v. Fid. Nat'l Title Ins. Co., No. 399 Civ. 1966M, 2001 WL 1172215, at*7 (N.D. Tex. Sept. 28, 2001); Fluid Tech., Inc. v. CVJ Axles, Inc., 964 P.2d 614, 616 (Colo. Ct. App. 1998). 
of a lawsuit. ${ }^{162}$ Surely, providing information to a physician in the hopes that the physician will write prescriptions for the medication is sufficient and within the pecuniary interest of the manufacturer.

Seemingly, in jurisdictions adopting anything but a near privity standard, Conte should find support. Indeed, Conte's analysis is not new. The foreseeability of contact between a physician and a drug's manufacturer and its implications on duty has been recognized for decades. For example, in Wechsler v. Hoffman-La Roche, ${ }^{163}$ a plaintiff sued the manufacturer of a prescription drug for the wrongful death of his intestate alleging that the manufacturer was liable for misrepresentations made to the plaintiff's doctor upon which the doctor had relied to write a prescription. The plaintiff alleged causes of action based on fraud, negligence and implied warranty. The defendant moved to dismiss all three claims in their entirety, but the trial court disagreed with the manufacturer's assertion that it could not be liable for the woman's death because it had not interacted with the woman. The court noted that "[i]f a more direct nexus between the fraudulent misrepresentation and the intestate is essential, it may be supplied by the circumstances that the physician who prescribed the drug was acting on behalf of the intestate and the fraud committed on the doctor was, therefore, a fraud upon the intestate." $" 164$

Interestingly, the Wechsler court relied upon the case of Marcus v. Specific Pharmaceuticals, Inc. ${ }^{165}$ In Marcus, the administrator of a mother's estate brought suit against the manufacturer of adult and child suppositories for the death of the woman's child. The action alleged negligence for failure of the manufacturer to make a suppository safe enough for very young children and for failing to provide adequate information to the prescribing physician. The complaint did not allege misrepresentation or concealment as possible alternative theories. The court concluded:

Moreover, it is difficult to see on what basis this defendant can be liable to plaintiff. It made no representation to plaintiff, nor did it hold out its product to plaintiff as having any properties whatsoever. To physicians it did make representations. And should any of these be false it might be claimed with propriety that they were made for the benefit of the ultimate consumers. But there is no such claim. The sole claim is not

162. Restatement (Second) of Torts $\S 552 \mathrm{cmt}$. d.

163. Weschler v. Hoffman-La Roche, Inc., 99 N.Y.S.2d 588 (N.Y. Sup. Ct. 1950).

164. Id. at $541-42$.

165. Marcus v. Specific Pharmaceuticals, Inc., 191 Misc. 285, 287, 77 N.Y.S.2d 508, 509. Justice Parbin did dismiss the warranty claim in Wechsler based on a lack of privity between the manufacturer and the plaintiff's intestate. $I d$. at 542 . 
misrepresentation or even concealment, but a negligent failure to give adequate information, and in some instances a failure to use adequate means to call attention to the information given. It may be safely conceded that these allegations would be sufficient if the product were sold to the public generally as a drug for which no physician's prescription was necessary. The situation alleged is materially different.

Marcus v. Specific Pharmaceuticals, 191 Misc. 285, 287, 77 N.Y.S.2d 508, 509-10 (N.Y. Sup. 1948) (emphasis added).

Although Wecshler and Marcus do not stand for the proposition that a manufacturer can be liable for another's product, these cases move the analysis one step closer to the proverbial and ultimate bystander-or the patient - based on an interaction with the patient's prescribing doctor. Marcus is also distinct in that, unlike Conte, no misrepresentation or concealment claims were alleged in the suit. The allegations against Wyeth were not just based on a negligent failure to warn. Marcus suggests, at far back as 1948, that were such allegations to be presented, a drug manufacturer could be liable to "ultimate consumers" for representations it made to their doctors, regardless of privity with the consumers. Marcus suggests that a duty to disclose material information about a drug product does, in fact, exist between the manufacturer and doctors. That position is perfectly consistent with the learned intermediary doctrine.

The problem of foreseeability in Foster is this: the court determined that it is not foreseeable for a manufacturer to owe a duty to a purchaser of a generic medication. However, the Foster analysis conflates the relationship between foreseeability and duty. For a duty to arise, the question is not whether the defendant foresaw owing a particular duty to a plaintiff, but rather whether the defendant's conduct creates a foreseeable risk to a foreseeable plaintiff. Foster never answered the latter question; instead, the court answered the question of whether it was foreseeable that a manufacturer would owe a duty to a generic user.

Further, Foster's premise is based on an unstated assumption that prescription drugs are like other products. ${ }^{166}$ Indeed, no one would ever suggest that another person sue Ford Motor Company for injuries sustained from the use of a Chevrolet vehicle. Arguably, Foster states as much when it rejects foreseeability of the manufacturer's duty to generic consumers. With prescription drugs, often there is no consumer choice between manufacturers. Sometimes, the decision is dictated by the pharmacist, an insurer or someone

166. Even the pharmaceutical strongly resists this comparison. For instance, this position is stated in the very first sentence of the Introduction to an industry report for 2006. PHRMA ProfILE, supra note 66. 
other than an informed consumer purchasing the product because of a sales brochure regarding features of the brand name medication. ${ }^{167}$

Foster's reasoning also relies on the recognition that generic manufacturers may alter a label's warnings and instructions, as they deem appropriate, even without FDA approval. The case also suggests that generic manufacturers - despite having to incorporate the label of the pioneer - should not assume that the labels are "perfect." ${ }^{168}$ However, Foster virtually ignores the duty of the innovator to maintain the accuracy of its label as a continuing duty. ${ }^{169}$ Consequently, Foster views the duties of an innovator with respect to labeling as mutually exclusive with those of a generic.

More troubling, the Foster court's analysis merges tort and products liability concepts together to arrive at the conclusion that one cannot be liable for a misrepresentation to another when there is no privity between the two parties. In fact, in the entire opinion, only one sentence is devoted to describing when a duty arises to a plaintiff for negligent misrepresentations. The subsequent sentence answers the question summarily without any analysis:

The duty required for the tort of negligent misrepresentation arises when there is "such a relation that one party has the right to rely for information upon the other, and the other giving the information owes a duty to give it with care." (citations omitted). There is no such relationship between the parties to this case, as Brandy Foster was injured by a product that Wyeth did not manufacture. ${ }^{170}$

Not only does the opinion skirt the issue, but it seemingly resurrects privity as an element to establish foreseeability and, thus, a duty of care. Under such a requirement, even bystander liability in the most basic of product liability actions would be foreclosed. In Conte, however, the California appellate court noted the circularity of the argument and distinguished it quickly.

But the Foster court's analysis falters in the next step. As foreseeability is the principal determinant of duty, the foreseeability of harm to consumers of the generic drug in reliance on information disseminated about the brand name version should have some significance in considering whether a duty of care arises in these circumstances. But Foster does not address that point. Instead, it concludes-without further

167. Indeed, most states have drug-substitution laws allowing or requiring pharmacists to dispense the generic version of a drug when available. Pilkington \& Stevenson, supra note 63, at 45.

168. Foster, 29 F.3d at $169-70$.

169. Wyeth v. Levine, 129 S. Ct. 1187, 1197-98 (2009).

170. Foster, 29 F.3d at 171. 
discussion - that no duty lies because "Brandy Foster was injured by a product that Wyeth did not manufacture." But that is the very question posed - not the answer. ${ }^{171}$

At present, approximately 34 courts in 19 states have followed Foster's reasoning. ${ }^{172}$ Nine of these have occurred following the decision in Conte; of these, though, none have been extremely helpful in filling the foreseeability gap left by Foster. Instead, these cases have simply adopted Foster's reasoning without scrutiny. For instance, Huck v. Trimark Physicians Group, ${ }^{173}$ contained no substantive discussion of Conte or of brand name liability as the plaintiffs filed no opposition. Precedent from another pre-Conte case in the same circuit bound the court in Cousins v. Wyeth Pharmaceutical, Inc. ${ }^{174}$ In Schrock v. Wyeth, Inc. ${ }^{175}$ the court did not address either Conte or Foster. Instead, the federal district court refused to render an opinion absent a ruling from the state's highest court on the issue, noting that other dispositive issues existed in the case, such as the lack of causation and plaintiff's failure to meet the state's product identification requirement. In Moretti v. Wyeth, Inc. ${ }^{176}$ the court noted that Nevada, unlike California, does not recognize the tort of negligent misrepresentation in personal injury cases because Nevada does not recognize sections 310 and 311 of the Restatement (Second) of Torts. Further, in Fields v. Wyeth, Inc. ${ }^{177}$ there was no product identification, and the court upheld Arkansas' exclusivity of remedy rule in products liability cases. Similarly, in Stoddard v. Wyeth, Inc. ${ }^{178}$ a North Carolina district court from the same circuit as Foster, followed its leader and refused to allow the plaintiff to sidestep her exclusive remedy in products liability. The court in Burke v. Wyeth, Inc. ${ }^{179}$ held that Texas' remedy for products-related injuries is also exclusive and followed earlier Texas precedent on the issue. In Bartlett v. Mutual Pharmaceutical Co., ${ }^{180}$ the district court, while dismissing the case, refused to go so far as to say that New Hampshire would not recognize innovator liability. Finally, in Meade v.

171. Conte, 168 Cal. App. 4th at 109.

172. See Beck \& Herrmann, Scorecard, supra note 11. 2009).

173. Huck v. Trimark Physicians Group, No. LACV018947, slip op. at 1-2 (Iowa Dist. Feb. 27,

174. Cousins v. Wyeth Pharmaceutical, Inc., 2009 WL 648703, at *2 (N.D. Tex. Mar. 10, 2009).

175. Schrock v. Wyeth, Inc., 601 F. Supp. 2d 1262, 1266-68 (W.D. Okla. 2009).

176. Moretti v. Wyeth, Inc., 2009 WL 749532, at *3-4 (D. Nev. 2009).

177. Fields v. Wyeth, Inc., 613 F. Supp. 2d 1056, 1060-61 (W.D. Ark. 2009).

178. Stoddard v. Wyeth, Inc., 630 F. Supp. 2d 631, 633-34 (E.D.N.C. 2009).

179. Burke v. Wyeth, Inc., 2009 WL 3698480 , at *2-3 (S.D. Tex. 2009).

180. Bartlett v. Mutual Pharmaceutical Co., 659 F. Supp. 2d 279, 308 (D.N.H. 2009). 
Parsley, ${ }^{181}$ another case from the Fourth Circuit, the court merely parroted Foster's language to avoid extending foreseeability too far but offered no new analysis.

Clearly, after Foster and Conte, regardless of the source of a particular medication, both an innovator and a generic have continuing duties to maintain the accuracy of the relevant drug's label as long as the medication remains on the market. Both have potential liability for their failure to do so, and liability should be shared in relative proportion based upon the facts of the case. In Conte, this did not happen because the generic manufacturers escaped liability on the misrepresentation theories as they had not participated in making any representations to Conte's physician. Her doctor simply did not rely on their information, never interacted with their sales representatives and did not choose the manufacturer of the patient's drug. The physician wrote the prescription which was substituted by the pharmacist. Nonetheless, the fact that a generic manufacturer copies another's label should not relieve the first of its own liability for failing to adequately disclose information in its original label or via a supplemental label change later.

\section{Limitations on Conte-Potential Defenses}

Although Conte initially summoned a loud outcry from the pharmaceutical defense bar, it has not had the catastrophic impact that many commentators had predicted, due in large part to existing differences among states' products liability laws. If any impact is to be realized, perhaps it will be in arguments advanced in courts that have yet to decide the issue. Or, perhaps Conte may serve as the ultimate consideration in a list of many factors to be weighed by plaintiffs' lawyers before choosing where to file a generic manufacturer case if given the option.

Prior to Conte, several states adopted statutory restrictions on actions that could comprise a products liability action. These restrictions arguably foreclose an outcome similar to Conte in these jurisdictions. ${ }^{182}$ These states,

181. Meade v. Parsley, 2009 WL 3806716, slip op. (S.D. W. Va. 2009).

182. These include Colorado, Louisiana and New Jersey, among others. The relevant statute in Colorado states:

"Product liability action" means any action brought against a manufacturer or seller of a product, regardless of the substantive legal theory or theories upon which the action is brought, for or on account of personal injury, death, or property damage caused by or resulting from the manufacture, construction, design, formula, installation, preparation, assembly, testing, packaging, labeling, or sale of any product, or the failure to warn or protect against a danger or hazard in the use, misuse, or unintended use of any product, or the failure to provide proper instructions for the use of any 
like Maryland, require, as an element of proving a prima facie products liability case, "product identification." Under that concept, a plaintiff must successfully demonstrate "that the actual product manufactured or distributed by the defendant caused injury to the plaintiff." 183 Thus, as long as a court views the action as products related, there is little chance it will adopt the reasoning in Conte.

For example, in Fields v. Wyeth, a federal district court relied on Arkansas state law and required the plaintiff, in order to maintain her action against the company, prove that the metoclopramide she took came from either Wyeth or Schwarz, notwithstanding the plaintiff's argument that the action sounded in negligent misrepresentation. In its analysis, the court assumed that even if it proved foreseeable to Wyeth (and Schwarz) that information provided to the plaintiff's physician might be relied upon to prescribe a generic version, the plaintiff could still not meet her burden of product identification to prove requisite proximate causation. ${ }^{184}$

Further, in order to escape extensions of Conte to certain cases, some within the pharmaceutical defense bar have suggested the use of disclaimers in labels to notify physicians and others that the warnings and instructions found in the brand name label do not apply to generic versions of the drug. ${ }^{185}$ For a number of reasons, however, the FDA will not allow the disclaimers and will reject, in practice or in theory, the proposed label. ${ }^{186}$ Still, the manufacturer could argue that in rejecting its proposed label or change that the

product.

CoLo. Rev. Stat. § 13-21-401(2) (emphasis added).

Louisiana's statute reads:

This Chapter establishes the exclusive theories of liability for manufacturers for damage caused by their products. A claimant may not recover from a manufacturer for damage caused by a product on the basis of any theory of liability that is not set forth in this Chapter ....

La. Rev. Stat. 9:2800.52 (emphasis added); see also Stahl v. Novartis Pharmaceuticals Corp., 283 F.3d 254 (C.A. 5 La. 2002) (holding claims of intentional torts are barred by Louisiana's Products Liability Act ("LPLA")); Leblanc v. Wyeth, Inc., 495 F. Supp. 2d 609 (W.D. La. 2007) (holding pharmacy could not be sued under the LPLA as it was neither a manufacturer or seller).

Similarly, New Jersey provides: “'Product liability action' means any claim or action brought by a claimant for harm caused by a product, irrespective of the theory underlying the claim, except actions for harm caused by breach of an express warranty.” N.J.S.A. § 2A:58C-1(b)(3); see also Stanley v. Wyeth, 991 So. 2d 31, 2007-80 (La. App. 1 Cir. 5/2/08) (holding fatal the inability of plaintiff to prove product identification); Swicegood v. Pliva, Inc., 543 F. Supp. 2d 1351 (N.D. Ga. 2008); Goldych v. Eli Lilly and Co., 2006 WL 2038436 (N.D.N.Y. 2006).

183. Fields v. Wyeth, 613 F. Supp. 2d 1056, 1060 (W.D. Ark. 2009).

184. Id. at 1060-61.

185. Jim Beck \& Mark Herrmann, A Thought Experiment on Conte v. Wyeth, Drug and Device Law Blog (Feb. 23, 2009), http://druganddevicelaw.blogspot.com/search/label/Conte.

186. $I d$. 
FDA's decision preempted state tort claims under Wyeth v. Levine. ${ }^{187}$ In Levine, the U.S. Supreme Court rejected federal preemption of a failure-towarn claim absent clear evidence that the FDA had either rejected proposed language or would not have approved stronger language in the drug's label. ${ }^{188}$ While technically appealing, this argument has weaknesses.

First, it elevates form over substance and potentially misreads Levine. A disclaimer as to applicability of a label merely distinguishes between manufacturers, not between a drug's side effects, risks or benefits. It is hard to see how a disclaimer as to the source of the medication would provide protection against a claim that the pioneer had knowledge or information regarding risks and benefits that should have been included in the original label or in a supplemental label, but failed to provide it. Secondly, Levine notes that a manufacturer has an ongoing responsibility to ensure accuracy of its label content at all times while the drug is marketed, ${ }^{189}$ including situations in which a drug's sponsor conducts new analysis of data previously submitted to the FDA which shows different risks or greater severity or frequency of adverse events. ${ }^{190}$ This post-FDA approval duty would be no less applicable in Conte, as the risks and frequency of tardive dyskinesia became known and studied after the FDA approved Reglan ${ }^{\circledR}$.

In addition, the use of disclaimers as an affirmative defense is based in contract and warranty theories of law rather than in tort law. Even then, there is a strong recognition that such defenses are not applicable under strict products liability theories. ${ }^{191}$ With negligence, public policy may dictate against disclaiming liability when facts surrounding the disclaimer, such as, risks of a particular drug, remain undisclosed. On the other hand, were a manufacturer to raise an argument that the disclaimer would give rise to questions in the prescribing physician's mind or to the consumer about the reliability of such a label, a factual issue could be created as to both the actual

187. Wyeth v. Levine, 129 S. Ct. 1187 ( 2009).

188. Id. at 1198 .

189. Id. at 1197-98 ("Yet through many amendments to the FDCA and to FDA regulations, it has remained a central premise of federal drug regulation that the manufacturer bears responsibility for the content of its label at all times."); see also 21 C.F.R. § 201.80(e); 21 C.F.R. § 314.80(b); 73 Fed. Reg. 49605 .

190. Levine, 129 S. Ct. at 1196-97.

191. See Restatement (Second) OF Torts $\S 402 \mathrm{~A} \mathrm{cmt}$. m "Warranty":

The consumer's cause of action does not depend upon the validity of his contract with the person from whom he acquires the product, and it is not affected by any disclaimer or other agreement, whether it be between the seller and his immediate buyer, or attached to and accompanying the product into the consumer's hands. 
or justifiable reliance of either thereon. However, the issue of actual or justifiable reliance thereon is generally a question of fact rather than law. ${ }^{192}$ For this question to be answered, it would most likely be submitted to a jury, resulting in lengthy and expensive litigation of the case through trial, as opposed to resolution at the summary judgment stage.

Another practical option for pioneers is to consider assigning the rights to a medication to a generic competitor once the exclusivity period concludes and the drug goes generic. In theory, the manufacturer would be also assigning liability for its original responsibilities with respect to the drug's label, notwithstanding the generic manufacturer's existing duty to update the label as discussed above. In practice, however, this option may prove difficult. First of all, in Conte, Wyeth had assigned the rights to Reglan ${ }^{\circledR}$ to Schwarz Pharmaceuticals in 2002. The agreement, however, contained an indemnification clause running in Schwarz's favor, presumably due to Schwarz's insistence on such a provision. The indemnification clause seems a prudent provision to any such contract since the clinical trials and postmarketing surveillance data conducted by the pioneer are not conducted in the presence of or by the generic manufacturer. Additionally, although an assignment of liability might curtail prospective labeling issues for the innovator, it would not necessarily protect the innovator from claims arising from its negligence prior to any assignment. Such an argument would be contrary to law and to policy promoting safety and efficacy of medications by allowing manufacturers to later waive or release themselves from their own liability.

To protect itself from potential liability, a pioneer might also consider voluntary withdrawal of the new drug application (NDA). In other words, the manufacturer would cease production and sale of the medication as the end of the exclusivity period nears and generics are due to come to market. This way, generics would have nothing to copy and no label to rely upon. Withdrawing the NDA would certainly obliterate any claim of justifiable reliance, necessary to prove a misrepresentation case. However, Hatch-Waxman anticipated these strategies and provided an exception to withdrawal that would allow generic manufacturers to continue marketing a generic version so long as the original drug was not withdrawn for safety and efficacy reasons. ${ }^{193}$ Accordingly, the Food Drug and Cosmetic Act requires a determination as to whether the drug

192. See, e.g., Syvrud v. Today Real Estate, Inc., 858 So. 2d 1125, 1130 (Fla. App. 2 Dist. 2003) ("The effect of the disclaimer in the context of an action for negligence, however, is a question of fact subject to the jury's determination of what was reasonable under the circumstances.").

193. Fox \& BennetT, supra note 95 , at 91. 
was withdrawn for safety and efficacy reasons when the withdrawal occurs prior to approving an ANDA or while there are approved ANDAs on the market. ${ }^{194}$ Thus, the withdrawal of an NDA does not necessarily prevent a generic manufacturer from continuing to market the generic medication. In the event the FDA determines the drug was withdrawn by the innovator for safety and efficacy reasons, it will publish a notice in the Federal Register, initiate a proceeding in accordance with 21 C.F.R. $\S 314.153(\mathrm{~b})$, and the drug will be removed from the list under 21 C.F.R. $\S 314.162$. Granted, that regulatory action might prevent further marketing of any generic version of the drug, but it would also foreclose any sales of the drug by the innovator while notifying the public and the plaintiffs' mass torts bar of undisclosed safety and efficacy issues prompting the drug's withdrawal.

\section{CONCLUSION}

Some suggest that it is unfair to expose innovators to liability in genericonly cases, especially when innovators gain no economic benefit from the sale of the generic product. However, this position ignores the basic reality that, for years, an innovator has been able to exclusively market an expensive medication, reaping a handsome return on its investment and, in some cases, billions of dollars of profit. This author desires to avoid the suggestion that there is any harm in earning a profit, however profit and responsibility come hand in hand. Perhaps greater responsibility for label changes should lie with the innovator since the innovator originally conducts the clinical trials and monitors the drug through post-marketing surveillance.

In addition, failure to warn and misrepresentation cases such as Conte sound in negligence, not strict liability. Liability would not exist were it not for negligence on the part of someone in formulating the label. Why should the manufacturer, the party originally responsible for having either placed erroneous information in its label or, worse, having withheld information from its label be exonerated simply because a generic manufacturer reproduced the product using the same active ingredient and same warning label? If risk is to be borne by the party best capable of mitigating that risk, it should not be a given that the innovator should be free of potential liability. That said, these cases are not open and shut, as causation and reliance remain significant obstacles. 
Some may argue that it is fundamentally unfair to the innovator if courts find preemption of labeling claims on the part of generic manufacturers. ${ }^{195}$ While this argument is meritorious, it does not alter the economic superiority the innovator has enjoyed over the years. It also disregards the Supreme Court's position in Levine as generic manufacturers retain their obligation to update labels under the Changes Being Effected provisions of 21 C.F.R. $\S 314.70$. Moreover, a balance can and should be struck with respect to contribution. That is, any factual determination by a court as to ultimate liability should be determined by a trier of fact, apportioning the appropriate fault to the innovator and the generic.

Conte's finding does not force brand name pharmaceutical manufacturers to become the insurers of generic manufacturers. By sharing liability to update drug labels, both the pioneer and the generic manufacturer remain potentially liable to the plaintiff. Conte did not create any new duty in this regard. Pioneers are already responsible for maintaining the label while their drug is on the market. This policy encourages, rather than insulates, drug companies to provide accurate information in their labeling throughout the entire life cycle of the medication.

Arguments that decry fundamental unfairness based on the lack of an ability to control the manufacturing process of another competitor are wholly irrelevant to the issue because negligent misrepresentation theories are based in information deficiencies, not manufacturing or design defects. Arguments that it is irresponsible for physicians to seek legally binding information about a drug from a company that does not itself produce, control, or profit from the sale of that drug are likewise misplaced. Oftentimes, the physician does not know whose product will be prescribed, nor does the physician compare specific factors, e.g., engine size, gas mileage, color, etc., such as one might compare in choosing an automobile. To the doctor, and to the FDA, all generics are bioequivalent to the innovator's drug.

Indeed, Foster's rationale should be limited rather than serve as the model for future generic-only cases. Not only does Foster choose to analyze the foreseeability of a duty rather than the foreseeability of risks by a defendant's conduct, but it suggests that generic drug manufacturers should bear not only the cost of liability associated with their product, but also that of the innovator's negligence in the original labeling. While this policy favoring the

195. An argument has been made that if federal law preempts liability against generic manufacturers that it would leave plaintiff without a remedy. See Schrock v. Wyeth, Inc., 601 F. Supp. 2d 1262, 1266 (W.D. Okla. 2009). If that were the case and the court were to follow Conte, then the innovator would be exposed unfairly to liability. 
assumption of such a risk is noteworthy, it is somewhat short-sighted because it protects the very innovator who may be responsible for the misleading label on the notion that it can no longer turn a profit on a medication once a generic version enters the market. This position ignores the likelihood that the innovator has potentially made billions of dollars off of the ability to sell its drugs for years without any competition, earning possibly more from the sale of the brand name drug than the generic manufacturer can ever hope to make. After all, the innovator is able to name its own price with impunity. Why should Foster provide such protections to a high-priced product at the expense of consumers? Why should our judicial policy condone favoring a product that is no longer commercially viable due to competition?

Foster illustrates further weakness in its failure to consider the learned intermediary doctrine. If providing the risks and benefits of a particular medication to a physician discharges the manufacturer's duty to warn or inform patients of the same, are generic manufacturers also relieved of the duty to warn? After all, it is commonly accepted that the manufacturer owes the duty to warn or inform to the physician, not the patient. Has the manufacturer thus assumed a duty of care to the physician of a generic patient who relies on the brand name manufacturer's label? Furthermore, what of the generic manufacturer's duties to warn? Absent the need for a label change, there is nothing new to be disclosed; thus, no duty on the part of the generic manufacturer to even warn the physician in the first instance. The generic manufacturer must rely upon the validity of the innovator's label. And notwithstanding the accuracy of that label, who must the generic manufacturer warn, the patient, the pharmacist, or the physician? Indeed, Foster and its progeny seem to criticize generic manufacturers for being scavengers, but neglect to analyze the extent of duties owed by them. According to Foster, "the party that actually controls the manufacturing and labeling of the product in question, and enjoys the profit of its sale, should bear legal liability for resulting injury." ${ }^{196}$ Such a position sounds in strict liability more so than in negligence.

It is critically important to consider the duty owed by the generics manufacturers. In failure to warn cases, it seems that liability could only exist if the plaintiff shows that the generic manufacturer possessed information about a drug that warranted label revisions, but chose instead not to change its label. If constructive knowledge proved enough, then would not the innovator

196. Fields v. Wyeth, 613 F. Supp. 2d 1056, 1061 (W.D. Ark. 2009); accord Moretti v. Wyeth, Inc., 2009 WL 749532, at 4 (D. Nev. 2009). 
also remain liable for not changing the label? These implications present serious hurdles to Foster's reasoning.

In the end, Foster, as is, could be utilized to stand for judicially created immunity of the innovator. In essence, after the innovator's exclusivity period ends and a drug goes generic, an innovator could never be liable for failure to warn in its label, even though it had actual knowledge of the need for such a warning, unless the plaintiff could prove that she took the brand name medication and that it caused or contributed to her injuries. This policy works well for nearly all other products, but it ignores the rather unique world of pharmaceutical products and the FDCA's labeling regime. Under this policy, there would be no incentive for the manufacturer to ever amend its label, as generics would bear absolute liability for the innovator's failure. The only consequence would then be the result of FDA enforcement action to require a label change on the part of the innovator.

Foster conflates the questions of duty and with proximate causation. These issues should remain as distinct addends of the equation. The concept of duty concerns itself with requirements on a person "to conform to a certain standard of conduct, for the protection of others against unreasonable risks." 197 Proximate cause, on the other hand, concerns itself with whether the defendant's "conduct has been so significant and important a cause that the defendant should be legally responsible." 198

As to duty, both the statutory framework and case law support the notion of a duty upon drug manufacturers - regardless of their position in line- to maintain the accuracy and adequacy of labels for products they sell. This duty is arguably perpetual - existing until manufacturers, both innovator and generic, are no longer involved in the commercial sale of that medication. This duty should then run to any foreseeable plaintiff for any foreseeable risk that conduct causes. If a manufacturer then breaches that duty, the court moves on, like with any other claim, to a question of causation, both factual and legal. Legal or proximate causation is not really a question of causation, but one of policy, a question of how far to extend liability or the responsibility for the conduct of the defendant. ${ }^{199}$

This is where the battle in these types of cases should be fought. However, proximate causation in this application, one that especially relies upon the foreseeability of harm and the extent to which we are willing to

197. W. Page Keeton, Elements of Cause of Action, in Prosser and Keeton on Torts 5:30, at 164 (5th ed. West Publishing Co.).

198. Id. at 273 .

199. Keeton, supra note 197, at 273. 
stretch it, should never be a proxy for duty. ${ }^{200}$ Unfortunately, that is how Foster characterized proximate causation and emphasized the elements for negligent misrepresentation. The court stated:

1) the defendant, owing a duty of care to the plaintiff, negligently asserts a false statement;

2) the defendant intends that his statement will be acted on by the plaintiff;

3) the defendant has knowledge that the plaintiff will probably rely on the statements, which if erroneous, will cause loss or injury;

4) the plaintiffs, justifiably, takes action in reliance on the statement; and

5) the plaintiff suffers damage proximately caused by the defendant's negligence.

Foster, 29 F.3d at 171 (emphasis in original).

In collapsing duty with causation, Foster has limited its potential to answer the questions left open by Conte, such as whether the physician exercised justifiable reliance on the PDR label, and whether, as a matter of proximate cause and not duty, it makes sense to hold the innovator liable. ${ }^{201}$ The policy Foster promotes is one-sided, seeming to exhibit more a distaste for the position of the generic manufacturer, suggesting that the generic manufacturer is a type of plagiarist while Congress and the pharmaceutical industry itself have authorized the generic manufacturer's very conduct by statute.

Before innovators become too concerned with the ramifications of Conte, it should be noted that the decision is not an ultimate one, but one on summary judgment. A trier of fact will still have to determine whether such a duty actually existed on their part to generic plaintiffs. In Conte, the doctor testified that he had reviewed the PDR for Reglan at some point in his residency, years before treating the plaintiff and, further, relied upon his research of the drug

200. Elizabeth Price Foley has observed:

$[\mathrm{P}]$ roximate or legal cause is undeniably a policy determination, anchored only by common sense and the quest for fairness. Legal cause is really nothing more than a gatekeeping mechanism whereby the trier of fact sifts through all possible factual causes and rejects those that are so microscopic, freakish, or otherwise attenuated that imposing liability on the defendant would work injustice.

Elizabeth Price, Toward A Unified Theory of Products Liability: Reviving the Causative Concept of Legal Fault, 61 TenN. L. Rev. 1277, 1351-52 (Summer 1994).

201. Other commentators have suggested a more straightforward approach:

Causative liability is a theory which holds that is $\mathrm{X}$ causes harm to $\mathrm{Y}$ (in both a factual and proximate sense), $\mathrm{X}$ should be held legally responsible. $\mathrm{X}$ is legally at fault even though he may have exercised all due care. $X$ therefore owes a duty to all individuals to refrain from acting in a manner that causes them harm. Thus, no elaborate inquiry into the questions of duty, the reasonableness of X's conduct, or defectiveness is necessary.

Id. at 1278 . 
in deciding to prescribe the drug to the plaintiff. If a jury accepts that such reliance is justifiable, even given the intervening medical articles in the meantime, perhaps liability rests with the manufacturer, innovator and generic alike. Or, perhaps the doctor's reliance is not justifiable, and the doctor bears an increased responsibility for having not kept current with knowledge within the field of medicine. Regardless, questions surrounding the doctor's research should remain distinct from the concept of duty. Otherwise, we shortcut to the answer, but leave an industry wondering just where liability to update labels should stand once a generic comes to market.

Between Conte and Foster lies the notion of joint liability and concurrent causation: liability if the original label contained a misrepresentation and the subsequent negligence of the generic.

The argument that the negligence of defendants . . . in failing to warn plaintiff and in allowing the dangerous condition of the premises to continue was an intervening force to break the chain of causation of the negligence of the realtors is answered by the settled rule that two separate acts of negligence may be the concurring proximate causes of an injury.

Merrill v. Buck, 375 P.2d 304, 311 (Cal. 1962). This naturally leads to questions as to whether negligence on the part of the generic is one of intervening or superseding negligence. Thus, while liability might exist for the generic, as Foster urges, the pioneer is not relieved of its negligence. This result is not entirely unfair because it allows for contribution from each party as to the amount of negligence while preserving the plaintiff's ability to recover for her injuries. The result also illustrates sound policy because it shifts the burden to those with an economic incentive, past or present, to disclose facts and risks as they are discovered as opposed to otherwise hiding such facts and risks from the public and their physicians. Moreover, the result also reflects sound medicine given that some adverse reactions and side effects may not manifest themselves for years.

If one views Conte as a decision that holds brand name manufacturers liable for all injuries sustained by patients of generic drugs, then the Conte ruling is an expansive and, no doubt, troubling pill for manufacturers to swallow. This is especially so from the lens of a warranty action, but less so for an action based in tort because even though a company may decide to not market a medication or has watched its patent expire and its revenues for that medication dwindle to nothing, the policy that patients should not be exposed to unreasonable risks of any medication as long as it remains on the market deserves protection. 